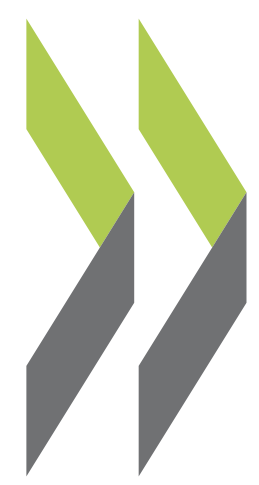

OECD Economics Department Working Papers No. 556

Income Inequality, Poverty

and Social Spending

Randall S. Jones

in Japan 
Organisation de Coopération et de Développement Economiques

ECONOMICS DEPARTMENT

INCOME INEQUALITY, POVERTY AND SOCIAL SPENDING IN JAPAN

ECONOMICS DEPARTMENT WORKING PAPERS No. 556

By Randall S. Jones 


\section{ABSTRACT/RÉSUMÉ}

\section{Income inequality, poverty and social spending in Japan}

Income inequality and relative poverty among the working-age population in Japan have risen to levels above the OECD average. This trend is partially explained by labour market dualism, with an increasing proportion of non-regular workers who are paid significantly less than regular workers, as well as by other factors, including the ageing of the workforce. Social spending as a share of GDP has been expanding in the context of population ageing, although it remains below the OECD average and the proportion received by low-income households is small. Consequently, the impact of social spending on inequality and poverty is weak compared to other OECD countries and inadequate to offset the deterioration in market income. The scope for increasing social spending is constrained by the fiscal situation. Instead, reversing the upward trend in inequality and poverty requires reforms to reduce labour market dualism and better target social spending on low-income households, particularly single parents.

This Working Paper relates to the 2006 OECD Economic Survey of Japan (www.oecd.org/eco/surveys/japan).

JEL classification: I32, I38.

Keywords: Income inequality, income distribution, absolute poverty, relative poverty, social spending, Gini coefficient, non-regular workers, labour market dualism, employment protection, Japan.

$* * * * * * *$

\section{Inégalité des revenus, pauvreté et dépenses sociales au Japon}

L'inégalité des revenus et la pauvreté relative parmi la population active ont progressé au Japon jusqu'à des niveaux supérieurs à la moyenne de l'OCDE. Cette évolution s'explique en partie par le dualisme du marché du travail - la proportion croissante de travailleurs non réguliers, qui sont rémunérés sensiblement moins que les travailleurs réguliers - ainsi que par d'autres facteurs comme le vieillissement de la population active. Les dépenses sociales en pourcentage du PIB se sont accrues du fait du vieillissement de la population, mais restent inférieures à la moyenne de l'OCDE, alors que le pourcentage de ces dépenses allant aux ménages à bas revenu est faible. L'incidence des dépenses sociales sur l'inégalité et la pauvreté est donc peu marquée, par rapport à ce qui est le cas dans les autres pays de l'OCDE, et insuffisante pour compenser la dégradation du revenu marchand. Les possibilités d'augmentation des dépenses sociales sont limitées par la situation budgétaire. Pour inverser la tendance à l'aggravation de l'inégalité et de la pauvreté, il faudrait plutôt mettre en œuvre des réformes visant à réduire le dualisme du marché du travail et à mieux cibler les dépenses sociales sur les ménages à faible revenu, en particulier les pères ou mères célibataires.

Ce Document de travail se rapporte à l'Étude économique de l'OCDE du Japon, 2006 (www.oecd.org/eco/etudes/japon).

Classification JEL : I32, I38.

Mots clés: Inégalité des revenus, distribution des revenus, pauvreté absolue, pauvreté relative, dépenses sociales, coefficient de Gini, travailleurs non réguliers, dualisme du marché du travail, protection de l'emploi, protection, Japon.

\section{Copyright OECD 2006}

Application for permission to reproduce or translate all, or part of, this material should be made to: Head of Publications Service, OECD, 2 rue André-Pascal, 75775 Paris Cedex 16, France. 


\section{TABLE OF CONTENTS}

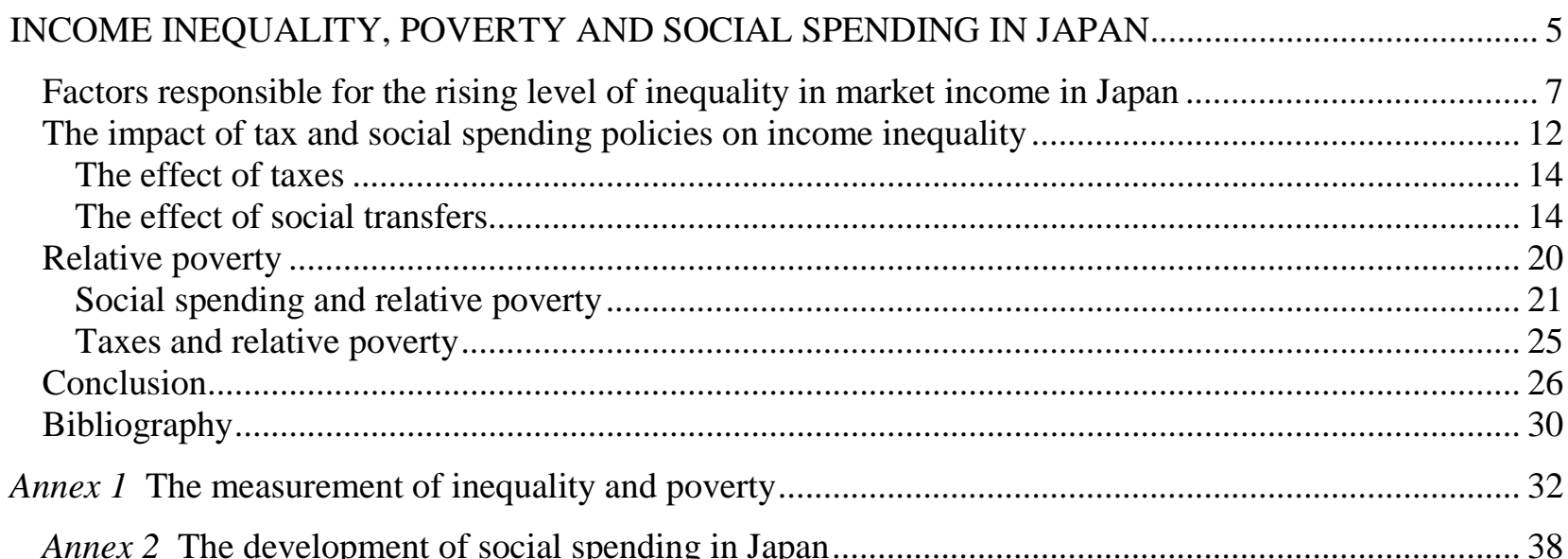

\section{Tables}

Table 1. Trends in the distribution of market income in OECD countries.............................................. 8

Table 2. A comparison of major characteristics of regular and non-regular workers ............................. 11

Table 3. Trends in the distribution of disposable income in OECD countries........................................ 13

Table 4. The impact of taxes and public social spending on income distribution in Japan ..................... 14

Table 5. The impact of tax and social spending policies on income distribution in OECD countries...... 15

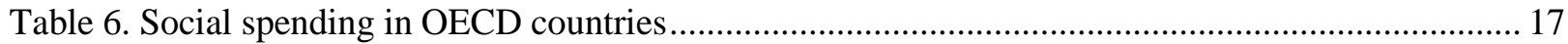

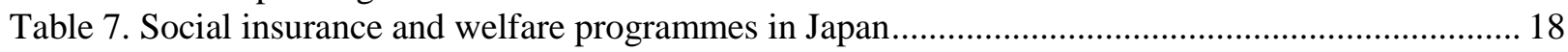

Table 8. The progressivity of transfers and taxes in OECD countries ................................................ 19

Table 9. The impact of tax and social spending programmes on poverty in OECD countries ................ 21

Table 10. Distribution of transfers and taxes in OECD countries ......................................................... 22

Table 11. Proportion of the population receiving government benefits in OECD countries ................... 23

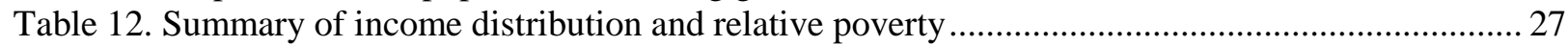

Table A1. Comparison of Japanese and OECD measures of the Gini coefficient ................................... 35

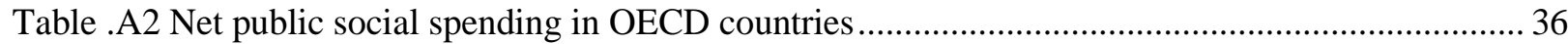

\section{Figures}

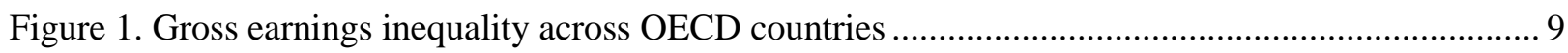

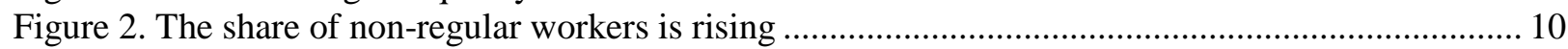

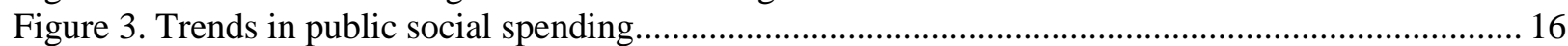

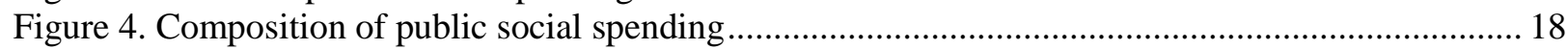

Figure 5. Relative poverty rates in households with children ............................................................. 24 


\section{ECO/WKP(2007)16}

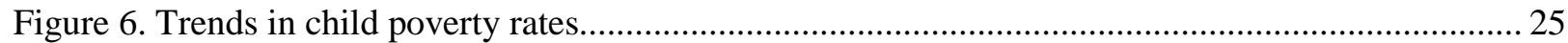

Figure 7. Changes in social spending and poverty among the working-age population .......................... 29

Figure A.1. Different measures of the Gini coefficient in Japan.............................................................. 34

\section{Boxes}

Box 1. Summary of recommendations to address inequality and relative poverty …............................. 28 
ECO/WKP(2007)16

\title{
INCOME INEQUALITY, POVERTY AND SOCIAL SPENDING IN JAPAN
}

\author{
Randall S. Jones ${ }^{I}$
}

1. A relatively equal income distribution has been a hallmark of postwar economic development in Japan. Around three-quarters of the population identify themselves as middle class. ${ }^{2}$ Lifetime employment and seniority-based wages, in which age and job tenure largely determine employee compensation, enhanced equality. A traditional support system based on families and firms has partially fulfilled the role played by the state in many other OECD countries. This approach has limited the growth of government spending and kept the tax burden at a moderate level.

2. However, there are a number of negative trends in income distribution and poverty:

- According to the Survey on the Redistribution of Income by the Ministry of Health, Labour and Welfare (MHLW), the Gini coefficient for disposable income increased by $11 \%$ between the mid-1980s and 2000. The OECD's comparative analysis of member countries found a similar trend for Japan. This report, which is based on the MHLW's Comprehensive Survey on Living Conditions, ${ }^{3}$ shows a $13 \%$ rise between the mid-1980s and 2000, compared to an OECD average of $7 \% .^{4}$ Consequently, the level of income inequality in Japan was slightly above the OECD average in 2000 (see Table 3 below). ${ }^{5}$

1. Randall S. Jones is head of the Japan/Korea Desk in the Economics Department of the OECD. This paper is based largely on material from the OECD Economic Survey of Japan published in July 2006 under the authority of the Economic and Development Review Committee (EDRC). The authors would like to thank Andrew Dean, Val Koromzay, Willi Leibfritz and Tadashi Yokoyama for valuable comments on earlier drafts. Special thanks go to Roselyne Jamin for technical assistance and to Nadine Dufour and Lillie Kee for technical preparation.

2. See, for example, Asia's New Giant, Chapter 1. This view of Japan was re-enforced by the OECD Economic Outlook (1976), which placed Japan with Norway and Sweden in the group of countries with the most equally distributed income. However, it should be noted that the data, based on the National Survey of Family Income and Expenditure, excluded agricultural households and under-reported property income and social security, making international comparisons of inequality difficult (see Bauer and Mason, 1992).

3. Two other surveys by the Japanese government also show increases in the Gini coefficient over the same period. The Family Income and Expenditure Survey reports a rise of 6\% between the average of 1984-86 and the average of 2002-04. The National Survey of Family Income shows an 8\% increase between 1984 and 1999 (the latest year available). The various income surveys are discussed in Annex 1.

4. For the 23 countries for which data are available. The OECD report (Förster and Mira d'Ercole, 2005) is based on data drawn from national sources on a standardised basis that adjusts household income by household size and uses common methodology and definitions to overcome many of the issues that limit cross-country and inter-temporal comparisons of income distribution and poverty (see Annex 1 for an explanation of the data and concepts used in this paper).

5. The estimate of the Gini coefficient from the Survey on the Redistribution on Income -- at 38.1 in 1999 -suggests a much higher level of inequality than the estimate of 31.4 reported in the OECD's comparative analysis. The reason for the difference is that the former is not adjusted for family size (see Annex 1). 
- The relatively large share of elderly in Japan and rapid population ageing partially explain the high and rising level of inequality. However, the Gini coefficient for the 18 to 65 age group shows the same trend as the coefficient for the entire population (see Table 3 below).

- Changes affecting those at the lower end of the income distribution are of particular concern. While the top income quintile's share of disposable income increased between 1985 and 2000, the share of the bottom quintile declined. Consequently, the ratio between the top and bottom quintiles rose from 4.4 in the mid-1980s to 5.6 in 2000, well above the OECD average of 4.5. ${ }^{6}$

- The proportion of the population living in absolute poverty ${ }^{7}$ increased by 5 percentage points between the mid-1980s and 2000 in Japan, the only OECD country to record an increase.

- The proportion of the population in relative poverty, defined as less than one-half of the median household disposable income, surpassed $15 \%$ in 2000 in Japan, the fifth highest in the OECD area and well above the average of $10 \%$. Relative poverty is also high among the working-age population (see Table 9 below).

- The average income of those in relative poverty is low compared to other OECD countries. Consequently, the amount of income transfers needed to raise all those in poverty up to the $50 \%$ threshold in Japan - the poverty gap - is the third largest in the OECD area.

In contrast to income distribution, the distribution of wealth has become more equal since the early 1990s following the collapse of the asset price bubble. ${ }^{8}$ However, international comparisons of the distribution of wealth are problematic due to data issues. Finally, it should be noted that the international comparisons calculated by the OECD end in the year 2000. ${ }^{9}$ The trends in inequality and poverty discussed in this paper, therefore, should not be attributed to the policies of the current government, which took office in 2001, but instead reflect more long-run developments.

3. Rising income inequality and relative poverty may be a concern to policymakers when they exacerbate the social exclusion of poorer persons, with negative consequences for the well being of those individuals as well as for society as a whole. ${ }^{10}$ Moreover, it may increase demands for hikes in public

6. This paper focuses on the Gini coefficient, which provides a measure of inequality that is less sensitive to changes in the two extremes of the income distribution. Two other measures of income concentration -mean-log deviations and squared coefficient of variation -- also report an increase in income inequality in Japan during the latter half of the 1990s (Förster and Mira d'Ercole, 2005).

7. Defined as an income less than one-half of the median disposable income in 1985 and adjusted for price increases in subsequent years. However, there are a number of difficult statistical issues in calculating an absolute poverty threshold (see Annex 1). Consequently, this paper will focus on relative poverty.

8. The Gini coefficient on the distribution of housing and residential land fell from 68 in 1989 to 57 in 1999.

9. Japanese surveys of household income show different results for trends in inequality since 2000. The Survey on the Redistribution of Income, which is drawn from the same sample on which the OECD's international comparison is based, reports that the Gini coefficient in 2002 (the latest year available) was unchanged from its 1999 level of 38.1. The National Survey of Family Income and Expenditure reports an increase of 2\% between 1999 and 2004. However, the Family Income and Expenditure Survey showed a $5 \%$ decline in the Gini coefficient over that period.

10. On the other hand, larger income inequalities may boost economic growth by raising incentives to work, save and invest. OECD analysis of this issue found some evidence that a wider income distribution is positive for growth. However, it explains very little of the differences in growth rates across countries and over time (Arjona et al., 2001). 
expenditure to counter rising poverty, resulting in tax increases that have negative implications for growth. This paper begins by examining the factors responsible for the increasing inequality in market income in Japan, followed by an overview of the impact of social spending on income distribution. The third section discusses the issue of relative poverty. The paper concludes with recommendations to counter the upward trend in income inequality and poverty.

\section{Factors responsible for the rising level of inequality in market income in Japan}

4. Between the mid-1980s and 2000, the distribution of market income became significantly less even in Japan. The Gini coefficient of market income inequality for the total population rose by 9.4 percentage points over that period, a large increase compared to the OECD average of 4.3 points (Table 1). ${ }^{11}$ The deceleration of economic growth following the collapse of the bubble and the resulting rise in the unemployment rate may have played a role. ${ }^{12}$ However, the trend toward greater market income inequality was already evident in the second half of the 1980s, a period of rapid growth. ${ }^{13}$

5. Population ageing has contributed to higher inequality in market income through three channels. First, the elderly have less income than the working-age population. The increase in the share of elderly from $10 \%$ of the Japanese population in the mid-1980s to $17 \%$ in 2000 raised the level of inequality because of larger between-group income differences. Second, the level of inequality of market income among those over age 65 is higher than for the 18 to 65 age group, reflecting the fact that a smaller portion of the over 65 age group is in the labour force. Indeed, the Gini coefficient for the over 65 age group in Japan in the mid-1980s was 47.3 compared to 30.9 for the working-age population (Table 1). The rising share of elderly in the population thus boosted the level of inequality of market income for the total population. Third, the degree of market income inequality among the elderly in Japan has risen sharply, as shown by the 15.6 percentage-point increase in the Gini coefficient for the over 65 age group since the mid-1980s, moving it toward the OECD average. The rising trend is partly explained by changes in living arrangements: the proportion of the elderly living alone or with a spouse rose from $32 \%$ in 1985 to $47 \%$ in 2000 , increasing the number of households with older persons reporting low incomes.

6. To the extent that higher market income inequality reflects population ageing, the observed increase may be less of a concern as it does not necessarily imply higher inequality in disposable income or greater relative poverty, given the importance of pension benefits (see below). Moreover, the elderly have generally accumulated significant wealth, in part to finance their retirement. ${ }^{14}$ Data on poverty and disposable income do not take account of dis-saving by older persons. Given the fact that income distribution and poverty statistics for the elderly are affected by changes in living arrangements and dis-saving, this paper focuses primarily on the working-age population, which also experienced a significant rise in inequality. Indeed, the Gini coefficient of market income for the 18 to 65 age group rose

11. Nevertheless, it should be noted that the level of inequality of market income in Japan in 2000, at 41.0, was below the OECD average of 44.3.

12. The unemployment rate in the OECD area is positively correlated with the Gini coefficient, suggesting that higher unemployment increases inequality (Burniaux, Padrini and Brandt, 2006). However, among the five OECD countries that experienced rising unemployment in the second half of the 1990s, only two (Japan and the Czech Republic) recorded increasing inequality in labour earnings.

13. Indeed, the Gini coefficient for the total population increased by 5.3 percentage points between 1985 and 1994, when real output was growing at an average annual rate of $3.2 \%$, and it rose by 4.1 points between 1994 and 2000 when real output was growing at a $1.2 \%$ rate.

14. In the mid-1990s, Japanese households headed by a person aged 67 or above had a stock of marketable assets of around nine times their annual disposable income in the case of singles and 3.6 times higher in the case of couples (Disney et al., 1998). In both cases, the wealth to income ratios were more than double the amount for a household headed by someone below the age of 55 . 
by 5.2 percentage points between the mid-1980s and 2000, bringing it closer to the OECD average (Table 1). In particular, there was a marked difference between trends in Japan and those in most other OECD countries during the latter half of the 1990s. While the average OECD Gini coefficient was almost unchanged, the coefficient for Japan increased by 2.3 percentage points, the third largest increase in the OECD area.

Table 1. Trends in the distribution of market income in OECD countries Gini coefficient (multiplied by 100) ${ }^{1}$

\begin{tabular}{|c|c|c|c|c|c|c|}
\hline & \multicolumn{3}{|c|}{ Level of the Gini coefficient } & \multicolumn{3}{|c|}{ Percentage-point change in the level } \\
\hline & Mid-1980s & Mid-1990s & $\begin{array}{c}\text { Around } \\
2000\end{array}$ & $\begin{array}{l}\text { Mid-1980s to } \\
\text { mid-1990s }\end{array}$ & $\begin{array}{l}\text { Mid-1990s } \\
\text { to } 2000\end{array}$ & $\begin{array}{c}\text { Mid-1980s } \\
\text { to } 2000\end{array}$ \\
\hline A. Japan & & & & & & \\
\hline $\begin{array}{l}\text { Total population } \\
\text { Working-age population }{ }^{2} \\
\text { Elderly population }\end{array}$ & $\begin{array}{l}31.7 \\
30.9 \\
47.3\end{array}$ & $\begin{array}{l}36.9 \\
33.8 \\
57.5\end{array}$ & $\begin{array}{l}41.0 \\
36.2 \\
62.9\end{array}$ & $\begin{array}{r}5.3 \\
2.9 \\
10.2\end{array}$ & $\begin{array}{l}4.1 \\
2.3 \\
5.4\end{array}$ & $\begin{array}{r}9.4 \\
5.2 \\
15.6\end{array}$ \\
\hline B. OECD average ${ }^{3}$ & & & & & & \\
\hline $\begin{array}{l}\text { Total population } \\
\text { Working-age population }{ }^{2} \\
\text { Elderly population }\end{array}$ & $\begin{array}{l}40.1 \\
35.4 \\
63.9\end{array}$ & $\begin{array}{l}44.2 \\
39.2 \\
65.5\end{array}$ & $\begin{array}{l}44.3 \\
39.3 \\
65.1\end{array}$ & $\begin{array}{l}4.1 \\
3.8 \\
1.6\end{array}$ & $\begin{array}{r}0.2 \\
0.1 \\
-0.4\end{array}$ & $\begin{array}{l}4.3 \\
3.9 \\
1.2\end{array}$ \\
\hline
\end{tabular}

1. The Gini coefficient is defined as the area between the Lorenz curve (which plots cumulative shares of the population, from poorest to richest, against the cumulative share of income that they receive) and the 45-degree line, taken as a ratio of the whole triangle. The values, which range from 0 in the case of perfect equality and 1 in the case of perfect inequality, are multiplied by 100 to give a range of 0 to 100 for the Gini coefficient.

2. The 18 to 65 age group.

3. For the following 14 countries: Australia, Canada, Denmark, Finland, France, Germany (old Länder only), Italy, Japan, the Netherlands, New Zealand, Norway, Sweden, United Kingdom and the United States.

Source: Förster and Mira d'Ercole (2005).

7. The relatively large increase in market income inequality among the working-age population during the latter half of the 1990s is somewhat surprising given the significant decline in capital income, which is marked by the highest degree of inequality among income components. ${ }^{15}$ This suggests that rising inequality of labour earnings, which account for about $80 \%$ of households' market income, was the key factor. Indeed, the earnings of those in the bottom income quartile have fallen as a share of total earnings since the mid-1980s (Förster and Mira d'Ercole). ${ }^{16}$ However, growing market income inequality cannot be explained by the variation in wages paid to full-time workers, as Japan was one of only three OECD countries to record a decline in wage inequality between 1994 and 2003 (Figure 1). This finding is supported by the fact that the Gini coefficient of earnings of regular workers, who are primarily full-time workers, has remained fairly constant since 1987. In addition, the ratio of wages of full-time workers in the $90^{\text {th }}$ and $10^{\text {th }}$ percentiles in Japan in 2003 was below the OECD average, perhaps reflecting the impact of the seniority-based wage system, which limits differences between employees of similar ages and tenure. Moreover, the wage gap between blue and white-collar employees is small and the wage premium for

15. Capital income declined from $7.2 \%$ of household disposable income in 1994 to $3.7 \%$ in 2000 , reflecting falling interest rates and asset prices.

16. The minimum wage does not appear to be responsible for increasing inequality. The statutory minimum wage rose slightly from 32\% of the average hourly wage in 1995 (all workers at firms with 30 or more workers) to $34 \%$ in 2004. 
higher education is low. ${ }^{17}$ The increasing share of the labour force above the age of 50 is another factor raising inequality, given the fact that the distribution of wages is more unequal for older workers. ${ }^{18}$

Figure 1. Gross earnings inequality across OECD countries ${ }^{1}$ 1994-2003(2)

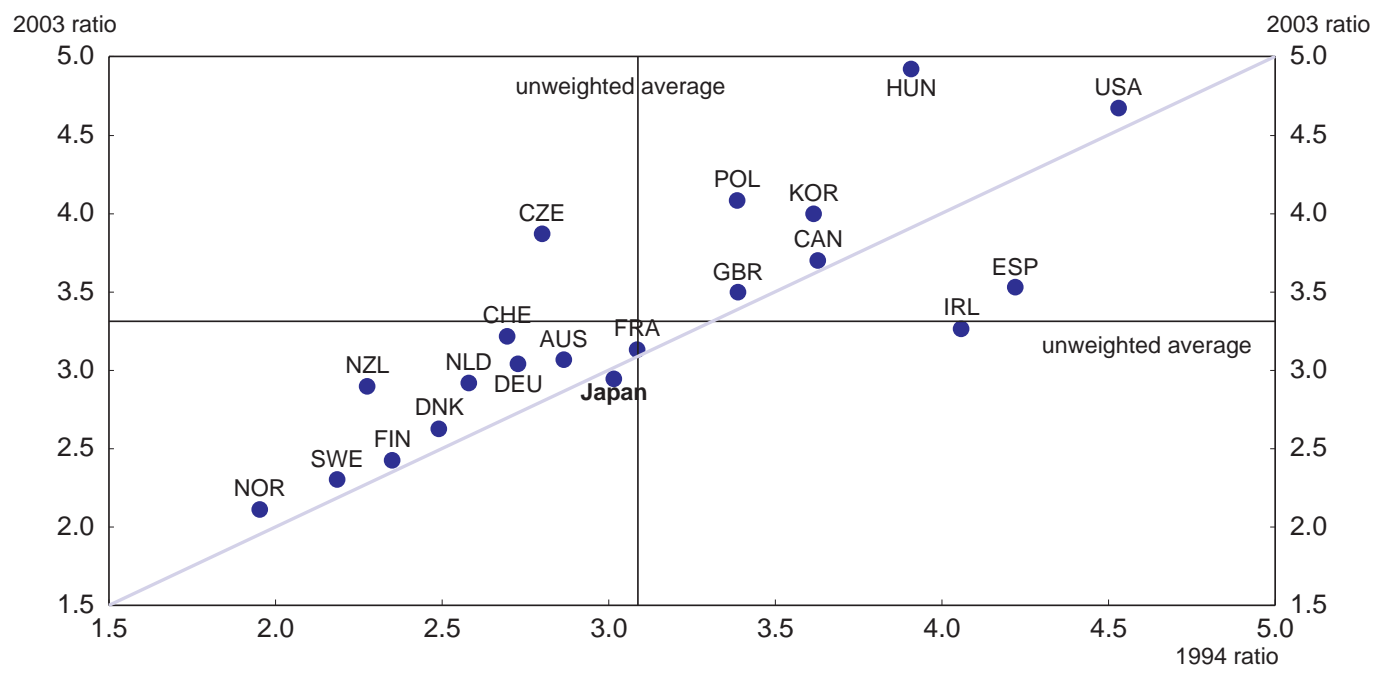

1. As measured by the ratio of the $90^{\text {th }}$ to $10^{\text {th }}$ percentile of the earnings of full-time workers. Countries located below the 45-degree line experienced a decline in gross earnings inequality between 1994 and 2003.

2. 1994-1999 for the Netherlands, 1994-2000 for Hungary and Ireland, 1994-2002 for France, Germany, Korea and Poland, 1995-2002 for Spain, 1996-2003 for Czech Republic and Denmark, 1997-2002 for Norway and 1997-2003 for Canada.

Source: OECD Employment Outlook (2004).

8. Instead, the growing proportion of non-regular workers is a key explanation of increased inequality in market income in Japan. Non-regular workers include part-time and dispatched workers (employed by temporary worker agencies) and temporary and short-term contract employees. ${ }^{19}$ On an hourly basis, part-time workers - who account for about two-thirds of non-regular workers - were paid only $40 \%$ as much as full-time workers in $2003 .{ }^{20}$ Consequently, the increase in the share of non-regular workers from 19\% of employees in 1994 to 30\% in 2005 (Figure 2) has significantly raised the overall level of inequality in Japan. ${ }^{21}$ Another study found that the wage differential between regular and non-

17. Men with a university degree earned $20 \%$ more on average than those with an upper secondary education.

18. In 1989, the Gini coefficient ranged between 21 and 25 for workers in the 25 to 50 age group, compared to 27 to 34 for those between 50 and 65. The increase in the proportion of the labour force between the ages of 50 to 65 - from $30 \%$ in 1989 to $36 \%$ in 2004 - lifted the Gini coefficient by about $1 \%$, assuming that the Gini coefficients for each age group remained at their 1989 level. The Gini coefficient for the working-age population increased $17 \%$ between the mid-1980s and 2000.

19. There is no legal distinction between regular and non-regular workers. The categories of dispatched workers, part-time workers and temporary employees are legally defined.

20. Part-time workers are defined as those working fewer hours on a daily or weekly basis than full-time employees in the same workplace. Workers can be classified as part-timers regardless of the length of the term of contract and whether it is fixed or not. Both the full-time and part-time categories include those employed on fixed-term or indefinite contracts.

21. For example, if all regular workers were paid an identical wage and all non-regular workers were paid $60 \%$ less, the increase in the proportion of non-regular workers from $19 \%$ to $30 \%$ would boost the variance of wage payments by about $31 \%$. 
regular workers has risen since the early 1990s (Higuchi and the Policy Research Institute, MOF, 2003). Moreover, the level of inequality among non-regular workers is relatively high - with a Gini coefficient of 48 in 2002 compared to 28 for regular workers - and has been increasing. Part-time workers earn on average only $40 \%$ as much per hour as full-time workers, a gap which appears too large to be explained by productivity differences. There appears to be a significant degree of wage discrimination, as the $60 \%$ gap between the average hourly wages of full and part-time workers is unlikely to be matched by the difference in productivity. In addition to the equity implications of greater labour market dualism, non-regular workers receive less on-the-job training, thus limiting their human capital and Japan's growth potential.

Figure 2. The share of non-regular workers is rising As percentage of total employed persons

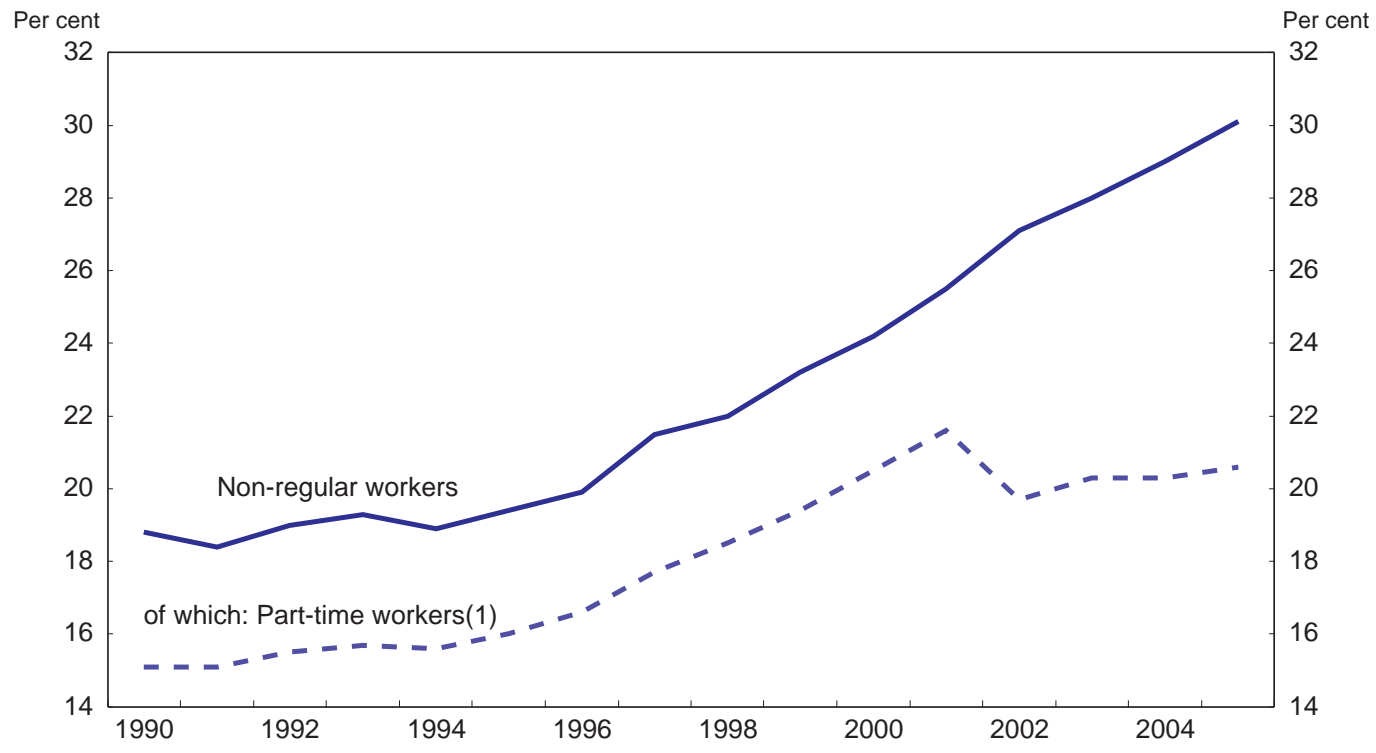

1. The significant fall in the number of part-time workers in 2002 and the rise in the other categories is thought to be due to a change in the questionnaire.

Source: Ministry of Internal Affairs and Communications.

9. Non-regular workers are a diverse group that includes young people on temporary contracts, married women working part-time and older persons who are re-hired by their former companies on fixedterm contracts. Non-regular employment provides opportunities for people to work in flexible and diverse ways that match their lifestyle. Their average age is three to four years older than regular workers, although a quarter of employees in the 20 to 24 age group are non-regular workers (Table 2). There are twice as many females employed as non-regular workers as males. Consequently, less than half of women employees are classified as regular workers. Non-regular workers also tend to be less educated, as only $12 \%$ have a university degree compared to $31 \%$ for regular workers, and are most prevalent in the service sector. Likewise, they are concentrated in smaller firms, where they are generally paid on an hourly or daily basis. Finally, non-regular employees work 30 hours a week on average compared to 40 hours for regular workers, although nearly half work more than 35 hours a week and are thus classified as full-time workers.

10. The lower wages paid to non-regular workers makes them attractive to firms, particularly since the economic malaise that began in the early 1990s. In addition, many are not included in enterprise-based social insurance schemes. Indeed, only about one-half of non-regular workers are covered by the Employees' Pension Scheme and health insurance and about two-thirds by employment insurance 
costs for firms. ${ }^{22}$ In a government survey that asked management why they hire non-regular workers, around half of firms cited reducing wage costs while nearly a quarter mentioned cutting non-wage costs (see the 2005 OECD Economic Survey of Japan).

11. Another important motivation for hiring non-regular workers is to enhance employment flexibility. In the survey cited above, more than a quarter of firms employing non-regular workers did so in order to cope with daily or weekly fluctuations in demand and to be able to adjust the number of employees to changes in the business cycle. Not surprisingly, 22\% of non-regular workers have less than one year of tenure and only $13 \%$ have more than ten years (Table 2, Panel J). In contrast, one-half of regular workers have been at their current firm for at least a decade. The flexibility afforded by using nonregular workers is needed to compensate for the high level of employment protection provided to regular workers. Indeed, Japan is ranked tenth out of 28 OECD countries in terms of the strictness of employment protection for regular workers, including voluntary practices by enterprises (OECD, 2004) ${ }^{23}$ As for restrictions on dismissal, judicial precedent was incorporated in the labour law in 2003. Any dismissal of workers that is not objectively justifiable and that is not considered to be acceptable by society's standards shall be deemed an abuse of power and therefore invalid. In addition, court cases have set four conditions that a firm must meet in the case of collective dismissals. First, it must show the economic necessity of reducing its workforce. Second, it must prove that there are no alternative measures that could achieve the necessary reduction. Third, it must demonstrate that the process of selecting employees for dismissal is reasonable and objective. Fourth, it must discuss the dismissals with the workers' union. Given these conditions, enterprises do not know beforehand if their efforts to rationalise their workforce will be accepted by the courts. ${ }^{24}$ Current efforts to incorporate judicial precedents into the law will help increase transparency.

12. The number of regular workers increased in 2005 for the first time in a decade. However, the joboffer ratio for full-time jobs was 0.65 in December 2005 compared to 1.45 for part-time jobs, indicating a continued preference for non-regular workers. There is thus a risk that the proportion of non-regular workers may ratchet up during the next economic downturn. Moreover, there are obstacles hindering the transition from non-regular to regular-worker status. Not surprisingly, $76 \%$ of the men and $69 \%$ of the women who are non-regular workers hope to become regular workers, according to a 2003 survey by the government. However, another government survey reported that only $23 \%$ of part-time workers who changed jobs in 2005 were hired as regular workers, compared to $31 \%$ in 1990.

\section{The impact of tax and social spending policies on income inequality}

13. As in other OECD countries, government policies in Japan play a significant role in reducing disparities in the distribution of market income. Consequently, measures of inequality are significantly

22. Employees who work less than three-quarters of the hours worked by regular employees (on a daily, weekly or monthly basis) are exempted from pension and health insurance contributions. Employees working less than one year or less than 20 hours a week are exempted from employment insurance. Such thresholds diminish the supply of labour as some employees work part-time to avoid having to make contributions to social insurance programmes.

23. Regression analysis using data from 19 OECD countries (including Japan) showed that employment protection increased inequality in some specifications of the equations (Burniaux, Padrini and Brandt, 2006).

24. Prior to 2003, the legal code did not specify any criteria for dismissing workers in principle. The labour law reform proposed by the government in 2003 restated that corporations have the right, in principle, to dismiss workers. However, this statement was eliminated from the bill due to resistance from opposition parties and labour unions. The new law states that collective dismissals should be consistent with "social common sense". 
smaller for disposable income, with a Gini coefficient of 31.4 in 2000 for the entire population (Table 3), compared to 41.0 for market income (Table 1). The impact of tax and social spending policies in reducing

Table 3. Trends in the distribution of disposable income in OECD countries Gini coefficient (multiplied by 100)

\begin{tabular}{|c|c|c|c|c|c|c|}
\hline \multicolumn{7}{|c|}{ A. Total population } \\
\hline & \multicolumn{3}{|c|}{ Level of the Gini coefficient } & \multicolumn{3}{|c|}{ Percentage-point change in the level } \\
\hline & Mid-1980s & Mid-1990s & 2000 & $\begin{array}{l}\text { Mid-1980s to } \\
\text { mid-1990s }\end{array}$ & $\begin{array}{l}\text { Mid-1990s to } \\
2000\end{array}$ & $\begin{array}{c}\text { Mid-1980s to } \\
2000\end{array}$ \\
\hline Australia & 31.2 & 30.5 & 30.5 & -0.7 & 0.0 & -0.7 \\
\hline Austria & 23.6 & 23.8 & 25.2 & 0.2 & 1.4 & 1.6 \\
\hline Canada & 29.0 & 28.3 & 30.1 & -0.7 & 1.8 & 1.1 \\
\hline Czech Republic & 23.2 & 25.8 & 26.0 & 2.6 & 0.2 & 2.8 \\
\hline Denmark & 22.9 & 21.3 & 22.5 & -1.6 & 1.2 & -0.4 \\
\hline Finland & 20.7 & 22.8 & 26.1 & 2.1 & 3.3 & 5.4 \\
\hline France & 27.5 & 27.8 & 27.3 & 0.3 & -0.5 & -0.2 \\
\hline Germany $^{1}$ & 26.3 & 27.7 & 27.5 & 1.4 & -0.2 & 1.2 \\
\hline Greece & 33.6 & 33.6 & 34.5 & 0.0 & 0.0 & 0.9 \\
\hline Hungary & 27.1 & 29.2 & 29.3 & 2.1 & 0.1 & 2.2 \\
\hline Ireland & 33.1 & 32.5 & 30.4 & -0.6 & -2.1 & -2.7 \\
\hline Italy & 30.6 & 34.8 & 34.7 & 4.2 & -0.1 & 4.1 \\
\hline Japan & 27.8 & 29.5 & 31.4 & 1.7 & 1.9 & 3.6 \\
\hline Luxembourg & 24.7 & 25.9 & 26.1 & 1.2 & 0.2 & 1.4 \\
\hline Mexico & 43.9 & 50.8 & 46.7 & 6.9 & -4.1 & 2.8 \\
\hline Netherlands & 23.4 & 25.5 & 25.1 & 2.1 & -0.4 & 1.7 \\
\hline New Zealand & 27.0 & 33.1 & 33.7 & 6.1 & 0.6 & 6.7 \\
\hline Norway & 23.4 & 25.6 & 26.1 & 2.2 & 0.5 & 2.7 \\
\hline Portugal & 32.9 & 35.9 & 35.6 & 3.0 & -0.3 & 2.7 \\
\hline Sweden & 19.8 & 21.2 & 24.3 & 1.4 & 3.1 & 4.5 \\
\hline Turkey & 43.5 & 49.1 & 43.9 & 5.6 & -5.2 & 0.4 \\
\hline United Kingdom & 28.7 & 31.2 & 32.6 & 2.5 & 1.4 & 3.9 \\
\hline United States & 33.8 & 36.2 & 35.7 & 2.4 & -0.5 & 1.9 \\
\hline Average $^{2}$ & 28.6 & 30.5 & 30.7 & 1.9 & 0.1 & 2.1 \\
\hline \multicolumn{7}{|c|}{ B. Working-age population } \\
\hline Australia & 30.4 & 29.4 & 29.5 & -1.0 & 0.1 & -0.9 \\
\hline Canada & 28.6 & 28.7 & 30.5 & 0.0 & 1.8 & 1.9 \\
\hline Denmark & 22.0 & 21.4 & 22.6 & -0.6 & 1.2 & 0.6 \\
\hline Finland & 20.5 & 23.4 & 26.0 & 3.0 & 2.6 & 5.5 \\
\hline France & 26.7 & 27.7 & 27.2 & 1.0 & -0.5 & 0.5 \\
\hline Germany $^{1}$ & 25.4 & 27.0 & 27.2 & 1.6 & 0.1 & 1.8 \\
\hline Italy & 30.5 & 34.9 & 34.5 & 4.4 & -0.4 & 4.0 \\
\hline Japan & 27.6 & 29.0 & 31.0 & 1.3 & 2.0 & 3.4 \\
\hline Netherlands & 23.3 & 25.4 & 25.0 & 2.1 & -0.4 & 1.7 \\
\hline New Zealand & 26.3 & 32.4 & 33.0 & 6.1 & 0.6 & 6.7 \\
\hline Norway & 22.2 & 24.9 & 26.0 & 2.7 & 1.1 & 3.8 \\
\hline Sweden & 22.4 & 21.6 & 24.2 & -0.8 & 2.6 & 1.8 \\
\hline United Kingdom & 27.7 & 30.4 & 31.9 & 2.7 & 1.5 & 4.2 \\
\hline United States & 32.6 & 35.1 & 34.6 & 2.6 & -0.5 & 2.0 \\
\hline Average $^{2}$ & 26.2 & 27.9 & 28.8 & 1.8 & 0.9 & 2.6 \\
\hline
\end{tabular}

1. Old Länder.

2. Average of the 23 countries in Panel $A$ and the 14 countries in Panel B. For information on the exact year for each country, see Förster and Mira d'Ercole (2005).

Source: Förster and Mira d'Ercole (2005). 
inequality increased between the mid-1980s and 2000, although this was more than offset by the deterioration in market income distribution. As a result, the inequality of disposable income distribution has risen for both for the total and the working-age populations. This section looks at the impact of taxes and social spending on equality.

\section{The effect of taxes}

14. In the early 1990s, the tax system reduced the Gini coefficient for market income in Japan by about 3\% (Table 4). However, tax reforms, which were aimed at increasing economic efficiency, have made the system less progressive. In 1986, the personal income tax had 15 rates, with a top rate of $70 \%$. In 1999 , it was reduced to only four, with a top rate of $37 \%$. As a result of lower progressivity, the impact of the tax system on the Gini coefficient had fallen to less than $1 \%$ by 2002 .

Table 4. The impact of taxes and public social spending on income distribution in Japan Gini coefficient (multiplied by 100)

\begin{tabular}{cc|cc|cc|cc}
\hline Year & $\begin{array}{c}\text { Market } \\
\text { income }\end{array}$ & \multicolumn{2}{|c|}{ Disposable income } & $\begin{array}{c}\text { Income distribution through } \\
\text { taxes }\end{array}$ & \multicolumn{2}{|c}{$\begin{array}{c}\text { Income distribution through } \\
\text { social spending }\end{array}$} \\
\hline $\begin{array}{c}\text { Gini } \\
\text { coefficient } \\
(\mathrm{A})\end{array}$ & $\begin{array}{c}\text { Gini } \\
\text { coefficient } \\
(\mathrm{B})\end{array}$ & $\begin{array}{c}\text { Decline in per } \\
\text { cent [(A-B)/A] }\end{array}$ & $\begin{array}{c}\text { Gini } \\
\text { coefficient } \\
(\mathrm{C})\end{array}$ & $\begin{array}{c}\text { Decline in per } \\
\text { cent [(A-C)/A] }\end{array}$ & $\begin{array}{c}\text { Gini } \\
\text { coefficient } \\
\text { (D) }\end{array}$ & $\begin{array}{c}\text { Decline in per } \\
\text { cent [(A-D)/A] }\end{array}$ \\
\cline { 2 - 8 } 1990 & 43.3 & 36.4 & -15.9 & 42.1 & -2.9 & 37.9 & -12.5 \\
1993 & 43.9 & 36.5 & -17.0 & 42.6 & -3.2 & 38.1 & -13.2 \\
1996 & 44.1 & 36.1 & -18.3 & 43.4 & -1.7 & 37.2 & -15.7 \\
\hline 1999 & 47.2 & 38.1 & -19.2 & 46.6 & -1.3 & 39.1 & -17.1 \\
2002 & 49.8 & 38.1 & -23.5 & 49.4 & -0.8 & 39.2 & -21.4 \\
\hline
\end{tabular}

Source: Japanese Trade Union Confederation (RENGO), (2006).

\section{The effect of social transfers}

15. In contrast to the tax system, the impact of social spending on income distribution has been relatively large and increasing (Table 4). Indeed, social spending reduced the Gini coefficient on market income by $12.5 \%$ in 1990 and $21.4 \%$ in 2002, although this includes the impact of pension benefits. Social spending thus accounted for almost all of the 9.7 percentage-point gap between the Gini coefficients for market income and disposable income for the total population in 2000 (Table 5). However, the impact on the working-age population - a 5.2 percentage point reduction - is only about half of the OECD average. The small impact of benefits on the income distribution among the working-age population in Japan reflects three factors: $i$ ) social spending is relatively low; $i i)$ social spending is concentrated on the elderly; and iii) the distribution of benefits between different income quintiles is less progressive in Japan. 
ECO/WKP(2007)16

Table 5. The impact of tax and social spending policies on income distribution in OECD countries

\begin{tabular}{|c|c|c|c|c|c|c|}
\hline & \multicolumn{3}{|c|}{$\begin{array}{l}\text { Percentage point difference } \\
\text { in Gini coefficients between } \\
\text { market and disposable income }\end{array}$} & \multicolumn{3}{|c|}{$\begin{array}{l}\text { Change in the impact of tax and benefit } \\
\text { systems on the distribution of disposable } \\
\text { income }\end{array}$} \\
\hline & Mid-1980s & $\begin{array}{l}\text { Mid- } \\
\text { 1990s }\end{array}$ & $\begin{array}{l}\text { Around } \\
2000\end{array}$ & $\begin{array}{l}\text { Mid-1980s to } \\
\text { mid-1990s }\end{array}$ & $\begin{array}{l}\text { Mid-1990s } \\
\text { to } 2000\end{array}$ & $\begin{array}{c}\text { Mid-1980s } \\
\text { to } 2000\end{array}$ \\
\hline \multicolumn{7}{|l|}{ A. Japan } \\
\hline $\begin{array}{l}\text { Total population } \\
\text { Working-age population }{ }^{2} \\
\text { Elderly population }\end{array}$ & $\begin{array}{r}3.9 \\
3.3 \\
13.3\end{array}$ & $\begin{array}{r}7.4 \\
4.9 \\
23.5\end{array}$ & $\begin{array}{r}9.7 \\
5.2 \\
29.1\end{array}$ & $\begin{array}{r}3.5 \\
1.6 \\
10.2\end{array}$ & $\begin{array}{l}2.2 \\
0.3 \\
5.7\end{array}$ & $\begin{array}{r}5.8 \\
1.9 \\
15.9\end{array}$ \\
\hline \multicolumn{7}{|l|}{ B. OECD average ${ }^{3}$} \\
\hline $\begin{array}{l}\text { Total population } \\
\text { Working-age population } \\
\text { W } \\
\text { Elderly population }\end{array}$ & $\begin{array}{r}13.4 \\
9.2 \\
37.2\end{array}$ & $\begin{array}{l}15.9 \\
11.2 \\
39.2\end{array}$ & $\begin{array}{l}15.2 \\
10.5 \\
38.1\end{array}$ & $\begin{array}{l}2.6 \\
2.0 \\
2.0\end{array}$ & $\begin{array}{l}-0.7 \\
-0.7 \\
-1.1\end{array}$ & $\begin{array}{l}1.9 \\
1.3 \\
0.9\end{array}$ \\
\hline
\end{tabular}

1. The difference in the Gini coefficient (multiplied by 100) for market income (Table 1) and disposable income (Table 3).

2. The 18 to 65 age group.

3. Average of the 14 countries shown in Table 1.

4. The decline between the mid-1990s and 2000 reflects falling unemployment rates.

Source: Förster and Mira d'Ercole (2005).

\section{The level of social spending is low}

16. Gross public social expenditure, including public pensions, in Japan reached $16.9 \%$ of GDP in 2001 (Table 6). Despite an increasing trend during the 1990s (Figure 3), Japan ranked $25^{\text {th }}$ among OECD countries, well below what would be expected given its level of income. However, gross public social spending does not provide a complete picture as it excludes the impact of the tax system on social expenditure (see Annex 1). Taking account of the tax system narrows the gap between Japan and other member countries by substantially reducing the OECD average (second column of Table 6). In addition, the provision of social expenditures is not restricted to government as most OECD countries require social spending by private-sector entities. Mandatory net private social spending in Japan amounted to $0.7 \%$ of GDP in 2001, slightly above the OECD average (third column). ${ }^{25}$ According to the most complete measure - the sum of net public spending and mandatory net private spending (the fourth column) - social spending in Japan is slightly below the OECD average and $14^{\text {th }}$ out of the 23 countries for which data are available.

25. Japan has a relatively high level of voluntary private net social spending, amounting to $2.5 \%$ of GDP, compared to the OECD average of $1.6 \%$. The business sector has traditionally played an important role in social spending, providing family benefits and services such as housing, recreation and hospital care in an effort to attract and keep highly qualified employees. However, such spending appears concentrated in large, successful firms that tend to pay higher wages, thus mainly benefiting regular workers and limiting its impact on reducing income inequality and poverty. 
Figure 3. Trends in public social spending As per cent of GDP

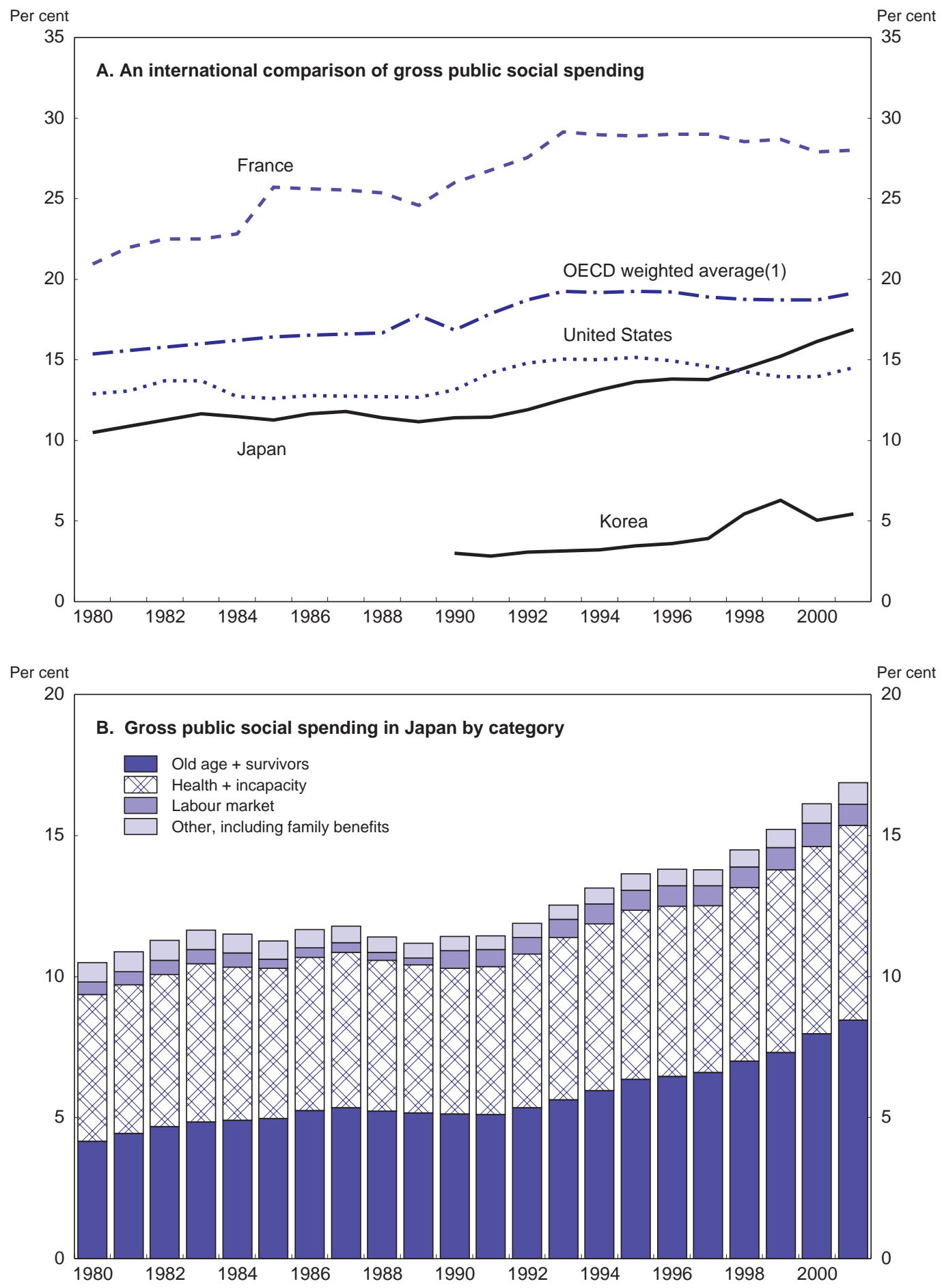

1. The OECD average does not include the Czech Republic, Hungary, Iceland, Korea, Mexico, Poland, the Slovak Republic and Turkey due to insufficient data. The national data is converted to US dollars using 2001 PPPs. Source: OECD, Social Expenditure Database, 1980-2001, available at www.oecd.org/els/social/expenditure. 
ECO/WKP(2007)16

Table 6. Social spending in OECD countries

Per cent of GDP, including pensions, in 2001

\begin{tabular}{|c|c|c|c|c|}
\hline Countries $^{1}$ & $\begin{array}{l}\text { Gross public } \\
\text { spending }\end{array}$ & Net public spending ${ }^{2}$ & $\begin{array}{l}\text { Net mandatory } \\
\text { private spending }\end{array}$ & $\begin{array}{l}\text { Total net public and } \\
\text { mandatory private } \\
\text { spending }\end{array}$ \\
\hline Sweden & 29.8 & 23.7 & 0.3 & 24.0 \\
\hline Denmark & 29.2 & 21.8 & 0.1 & 21.9 \\
\hline France & 28.5 & 25.2 & 0.0 & 25.2 \\
\hline Germany & 27.4 & 25.4 & 0.8 & 26.2 \\
\hline Austria & 26.0 & 20.6 & 0.5 & 21.1 \\
\hline Switzerland & 25.8 & & & \\
\hline Finland & 24.8 & 19.2 & 0.1 & 19.3 \\
\hline Belgium & 24.7 & 21.2 & 1.4 & 22.6 \\
\hline Italy & 24.4 & 20.9 & 1.1 & 22.0 \\
\hline Greece & 24.2 & & & \\
\hline Norway & 23.9 & 19.6 & 0.8 & 20.4 \\
\hline Poland & 22.2 & & & \\
\hline United Kingdom & 21.8 & 19.8 & 0.4 & 20.2 \\
\hline Netherlands & 21.4 & 18.0 & 0.4 & 18.4 \\
\hline Luxembourg & 20.8 & .. & .. & .. \\
\hline Portugal & 20.3 & & & \\
\hline Czech Republic & 20.1 & 18.7 & 0.0 & 18.7 \\
\hline Hungary & 20.1 & & & \\
\hline Iceland & 19.8 & 17.6 & 0.7 & 18.3 \\
\hline Spain & 19.6 & 16.7 & 0.0 & 16.7 \\
\hline New Zealand & 18.5 & 15.5 & 0.0 & 15.5 \\
\hline Australia & 18.0 & 17.1 & 0.7 & 17.8 \\
\hline Slovakia & 17.9 & 16.4 & 0.2 & 16.6 \\
\hline Canada & 17.8 & 17.1 & 0.0 & 17.1 \\
\hline Japan & 16.9 & 17.1 & 0.7 & 17.8 \\
\hline United States & 14.7 & 15.9 & 0.4 & 16.3 \\
\hline Ireland & 13.8 & 12.2 & 0.0 & 12.2 \\
\hline Turkey & 13.2 & & & \\
\hline Korea & 6.1 & 6.1 & 2.2 & 8.3 \\
\hline Mexico & 5.1 & 6.3 & 0.0 & 6.3 \\
\hline Average & 20.6 & 17.9 & 0.5 & 18.4 \\
\hline
\end{tabular}

1. Countries are ranked in descending order by gross public social spending.

2. Adjusts for the impact of the tax system on social expenditure.

Source: Adema and Ladaique (2005).

\section{Social spending is concentrated among the elderly}

17. Social outlays in Japan are focused on insurance systems for pensions, healthcare, unemployment and long-term nursing care (Annex 2). Total spending on these programmes amounted to nearly $80 \%$ of public social spending in FY 2003 (Table 7). Around 70\% of the outlays by social insurance programmes were for elderly persons. Such spending, combined with a relatively high rate of labour force participation of older workers, has helped maintain the income of the elderly at a fairly high level. Indeed, the disposable income of the over 65 age group in Japan is $84 \%$ of the 18 to 65 age group, compared to an OECD average of $76 \%$. In contrast to social insurance, spending on welfare programmes such as livelihood protection ${ }^{26}$ and family benefits is much lower, accounting for $5.5 \%$ of total public social spending.

26. In $2005,1.1 \%$ of the population received benefits from the Livelihood Protection Programme. 
ECO/WKP(2007)16

Table 7. Social insurance and welfare programmes in Japan FY 2003

\begin{tabular}{|c|c|c|c|c|c|}
\hline Revenue & $\begin{array}{c}\text { Trillion } \\
\text { yen }\end{array}$ & Per cent & Expenditure by scheme & $\begin{array}{c}\text { Trillion } \\
\text { yen }\end{array}$ & Per cent \\
\hline Insurance premiums & 54.6 & 54.0 & Social insurance & 76.5 & 74.3 \\
\hline Insured persons & 27.4 & 27.4 & Pension benefits & 43.0 & 41.0 \\
\hline \multirow[t]{2}{*}{ Firms } & 27.3 & 26.9 & Medical insurance & 14.7 & 14.0 \\
\hline & & & Healthcare for elderly & 10.7 & 10.2 \\
\hline General tax revenue & 27.8 & 27.8 & Long-term care & 5.1 & 4.9 \\
\hline Central government & 21.1 & 20.9 & Employment insurance & 2.0 & 1.9 \\
\hline Local government & 6.6 & 6.6 & Accident insurance & 1.0 & 1.0 \\
\hline \multirow[t]{9}{*}{ Income from capital } & 18.8 & 18.6 & Social welfare & 5.8 & 5.5 \\
\hline & & & Livelihood protection & 2.4 & 2.3 \\
\hline & & & Other social welfare & 2.5 & 2.4 \\
\hline & & & Family benefits and other & 0.9 & 0.8 \\
\hline & & & Civil servant pensions & 1.4 & 1.3 \\
\hline & & & Public health programmes & 0.6 & 0.6 \\
\hline & & & Administrative costs & 1.3 & 1.2 \\
\hline & & & Transfers to funds & 15.9 & 15.2 \\
\hline & & & Other & 3.4 & 3.2 \\
\hline Total & 101.3 & 100.0 & Total & 104.9 & 100.0 \\
\hline
\end{tabular}

Source: Ministry of Health, Labour and Welfare.

Figure 4. Composition of public social spending

Per cent of GDP in 2001

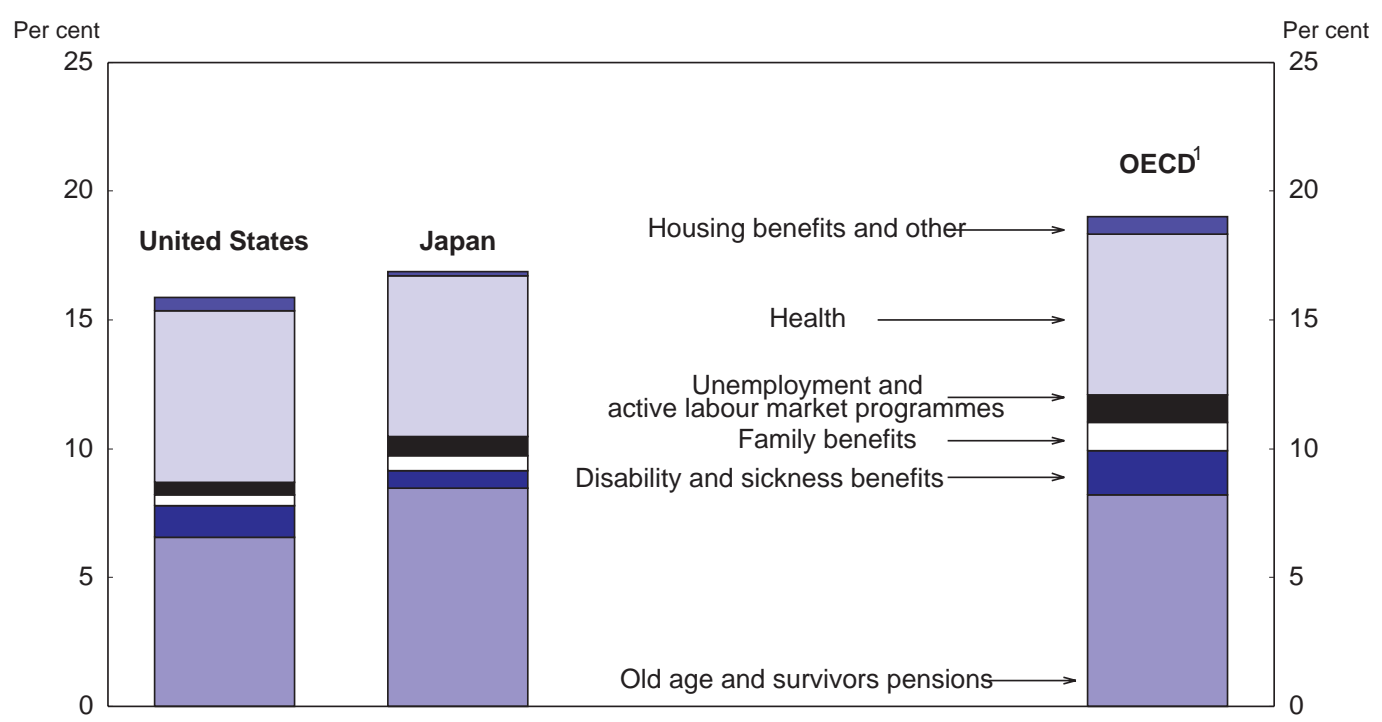

1. Weighted average of 29 countries.

Source: OECD, Social expenditure database. 
18. With the rising trend during the 1990s, expenditures on pensions and healthcare in Japan are larger than the OECD average (Figure 4). However, outlays for unemployment and active labour market policies are significantly less, reflecting the low rate of unemployment and the fact that a relatively low proportion of unemployed receive benefits (see below). In addition, spending on family benefits and disability and sickness payments is significantly smaller than the OECD average. In 2001, public old-age pensions per elderly person were 17 times larger than social spending per person under the age of 65 , a ratio that is double the OECD average, reflecting the low level of spending on the working-age population. In sum, Japanese social spending is somewhat below the OECD average and more concentrated on the elderly.

\section{Benefits are less concentrated on low-income households}

19. The third factor - the progressivity of social spending - is measured by the "quasi-Gini coefficient", which varies from -100 to 100 . For transfers, a value of zero indicates a flat rate that pays the same amount of transfer to each household. Positive values between zero and 100 indicate that the amount of transfers increases with private income. For pensioners, the quasi-coefficient is positive in most countries, including Japan, as the amount of benefits is linked to past income (Table 8). For the workingage population, in contrast, the quasi-Gini coefficient is negative as expected in most countries, indicating that the amount of transfers increase as the level of household income declines. In contrast, in Japan, the quasi-Gini coefficient for the 18 to 65 age group is positive, suggesting that the distributional impact of transfers on low-income households is relatively weak. ${ }^{27}$ As for direct taxes, the quasi-Gini coefficient in 2000 was 31.9 , indicating less progressivity than the OECD average of 44.1.

Table 8. The progressivity of transfers and taxes in OECD countries Quasi-Gini coefficients ${ }^{1}$ in 2000

\begin{tabular}{lrccc}
\hline & Japan & OECD average ${ }^{2}$ & Highest & Lowest \\
\cline { 2 - 5 } Cash transfers & & & & -11.9 \\
$\quad$ Pensions & 11.0 & 12.0 & 44.6 & -42.4 \\
$\quad$ Working-age & 3.3 & -7.2 & 33.8 & -38.3 \\
$\quad$ Total & 3.2 & -6.5 & 57.1 & 22.8 \\
Direct taxes & 31.9 & 44.1 & 57.3 & \\
\hline
\end{tabular}

1. This measure varies from -100 to 100 , with a value of zero for a flat rate that pays each household the same amount of transfer. It is calculated by comparing the share of social security benefits received by deciles ranked from the poorest to the richest. Values between zero and 100 mean that the share of transfers received increases with private income. Conversely, values between zero and -100 indicate that the share of transfers received decreases as income increases. Thus, negative numbers imply that a greater share of transfers go to the poor. For taxes, the coefficient is positive for all countries. Since taxes are deducted from incomes, the higher the coefficient, the more equalizing the impact of taxes.

2. For transfers, the average includes all OECD countries except Korea, Iceland and the Slovak Republic. For taxes, the average includes 19 countries.

Source: Whiteford (2006).

27. Transfers still have a redistributive effect as long as their quasi-Gini coefficient is below the Gini coefficient of market income. This is the case in all OECD countries, including Japan. 


\section{Relative poverty}

20. The increase in income inequality in Japan was accompanied by a rise in the relative poverty rate $^{28}$ - defined as an income that is less than $50 \%$ of the median - from $12.0 \%$ of the total population in the mid-1980s to $15.3 \%$ in 2000 . The OECD average increased from $9.4 \%$ to $10.6 \%$ over the same period. About a quarter of the increase in Japan was due to population ageing; the poverty rate would have only risen to $14.5 \%$ if the age-distribution of the population had remained unchanged from the mid-1980s. ${ }^{29} \mathrm{~A}$ second factor was the increase in the share of people living alone from $3.5 \%$ in the mid-1980s to $6.8 \%$ in 2000. This is due to more young people moving away from home to study and work and a rise in the share of elderly persons living alone from $1 \%$ to $3 \%$ of the total population. About half of the increase in the poverty rate is due to the increase in single-person households: the poverty rate would have only risen to $13.6 \%$ - rather than $15.3 \%$ - if the household structure had remained as in the mid-1980s. These factors also boosted poverty rates in other OECD countries. In particular, the share of single-person households increased from an average of $9 \%$ in the mid-1980s in the OECD area to $11 \%$ in 2000, nearly double the level of Japan. Japan's poverty rate would thus likely be significantly higher if its proportion of single households were not so far below the OECD average.

21. The relative poverty rate for the working-age population in Japan increased from $11.9 \%$ in the mid-1990s to $13.5 \%$ in 2000 compared to the OECD average of $8.4 \%$ (Table 9). The high level of poverty is surprising given the level of employment: only $2.8 \%$ of the population in Japan in 2000 lived in a household in which no one worked, compared to an OECD average of $9.4 \% .^{30}$ The 1.6 percentage point rise in poverty - the third largest in the OECD area - was due to changes in market income, ${ }^{31}$ reflecting the rise in wage dispersion in the context of increased labour market dualism.

28. Patterns in inequality and relative poverty over time are similar in most OECD countries. The cross correlation of the Gini coefficient and the relative poverty rate during the period 1970 to 2001 was 0.90 . The relative poverty rate is based on disposable income.

29. The rate of relative poverty for the over 65 age group fell from $23 \%$ to $21 \%$, although it remains well above the OECD average of $13 \%$.

30. This refers to the population living in households headed by a person of working age. The increase in poverty is consistent with data from the Ministry of Health, Labour and Welfare showing that the proportion of households with an income of less than 2 million yen rose from 14\% in 1998 to $18 \%$ in 2002 . In addition, the share of households with no savings doubled from 12 to 24\% between 1999 and 2005.

31. According to a study of poverty in households headed by a person of working age, changes in market income boosted the poverty rate by 2.4 percentage points. This was partially offset -0.7 percentage point by an increased number of two-worker households (Förster and Mira d'Ercole, 2005). In contrast, market income had almost no effect on poverty, on average, in the OECD area. 
ECO/WKP(2007)16

Table 9. The impact of tax and social spending programmes on poverty in OECD countries Relative income poverty as a percentage of the working-age population ${ }^{1}$

\begin{tabular}{lccc|crc}
\hline & \multicolumn{3}{c|}{ Mid-1990s } & & 2000 \\
& $\begin{array}{l}\text { Poverty } \\
\text { rate: } \\
\text { market } \\
\text { income }\end{array}$ & $\begin{array}{c}\text { Reduction in } \\
\text { poverty due } \\
\text { to tax/benefit } \\
\text { system }\end{array}$ & $\begin{array}{c}\text { Poverty rate: } \\
\text { disposable } \\
\text { income }\end{array}$ & $\begin{array}{c}\text { Poverty rate: } \\
\text { market } \\
\text { income }\end{array}$ & $\begin{array}{c}\text { Reduction in } \\
\text { poverty due } \\
\text { to tax/benefit } \\
\text { system }\end{array}$ & $\begin{array}{c}\text { Poverty rate: } \\
\text { disposable } \\
\text { income }\end{array}$ \\
\cline { 2 - 7 } Czech Republic & 17.7 & 14.6 & 3.0 & 19.5 & 15.7 & 3.8 \\
Denmark & 20.5 & 16.0 & 4.5 & 18.5 & 13.5 & 5.0 \\
Sweden & 18.6 & 14.5 & 4.2 & 16.2 & 11.0 & 5.1 \\
Netherlands & 17.6 & 11.4 & 6.2 & 14.9 & 9.0 & 5.9 \\
France & 26.1 & 19.4 & 6.8 & 24.1 & 18.1 & 6.0 \\
Norway & 14.2 & 7.5 & 6.7 & 14.5 & 8.5 & 6.0 \\
Finland & 18.1 & 12.7 & 5.4 & 15.3 & 8.8 & 6.4 \\
Germany & 18.6 & 11.3 & 7.2 & 20.5 & 12.5 & 8.0 \\
Australia & 20.5 & 13.0 & 7.5 & 20.5 & 11.9 & 8.6 \\
United Kingdom & 20.4 & 12.5 & 8.0 & 19.9 & 11.2 & 8.7 \\
New Zealand & 18.2 & 11.2 & 7.0 & 18.3 & 8.8 & 9.5 \\
Portugal & 16.6 & 6.6 & 10.0 & 15.7 & 6.1 & 9.6 \\
Canada & 17.8 & 8.4 & 9.4 & 16.0 & 5.7 & 10.3 \\
Italy & 23.6 & 10.9 & 12.7 & 21.8 & 10.3 & 11.5 \\
Ireland & 26.6 & 18.0 & 8.6 & 18.8 & 6.9 & 11.9 \\
Japan & $\mathbf{1 4 . 0}$ & $\mathbf{2 . 2}$ & $\mathbf{1 1 . 9}$ & $\mathbf{1 6 . 5}$ & $\mathbf{3 . 0}$ & $\mathbf{1 3 . 5}$ \\
United States & 18.7 & 5.2 & 13.5 & 18.0 & 4.3 & 13.7 \\
Average & 19.3 & 11.5 & 7.8 & 18.2 & 9.7 & 8.4 \\
\hline
\end{tabular}

1. Countries are ranked by the poverty rate of disposable income in 2000 .

2. Average of the 17 countries in the table. The decline in the impact of the tax/benefit system between the mid-1990s and 2000 reflects falling unemployment rates.

Source: Förster and Mira d'Ercole (2005).

\section{Social spending and relative poverty}

22. The tax and social spending programmes on poverty helped to limit the rise in relative poverty in the second half of the 1990s. However, its impact - at two to three percentage points in both the mid-1990s and 2000 - was much smaller than in the OECD area (Table 9). The relationship between public social spending and poverty outcomes is striking: relative poverty rates among the working-age population are lowest in countries where social spending (excluding healthcare) for that age group is highest (Förster and Mira d'Ercole, 2005). The high level of relative poverty in Japan is consistent with the low level of public social spending on the working-age population discussed above.

23. The impact of government programmes to reduce poverty depends not only on the amount of spending but also on the criteria used in its allocation. In principle, a carefully targeted system can significantly reduce poverty even when the total amount of spending is small. However, in Japan, the share of transfers allocated to households in the lower part of the income distribution is relatively small (Table 10). Indeed, the lowest income quintile received $15.7 \%$ of government transfers compared to an OECD average of $22.8 \%$. Consequently, transfers to the low-income quintile accounted for only $2.7 \%$ of total disposable income, well below the OECD average. In contrast, the share of transfers received by highincome households in Japan is larger than the OECD average. As a result, the ratio of the transfers received by the bottom and top quintiles was 0.8 in 2000 (as shown in the column on the far right) compared to an OECD average of 2.1, indicating that transfers are less targeted on the poor in Japan. 


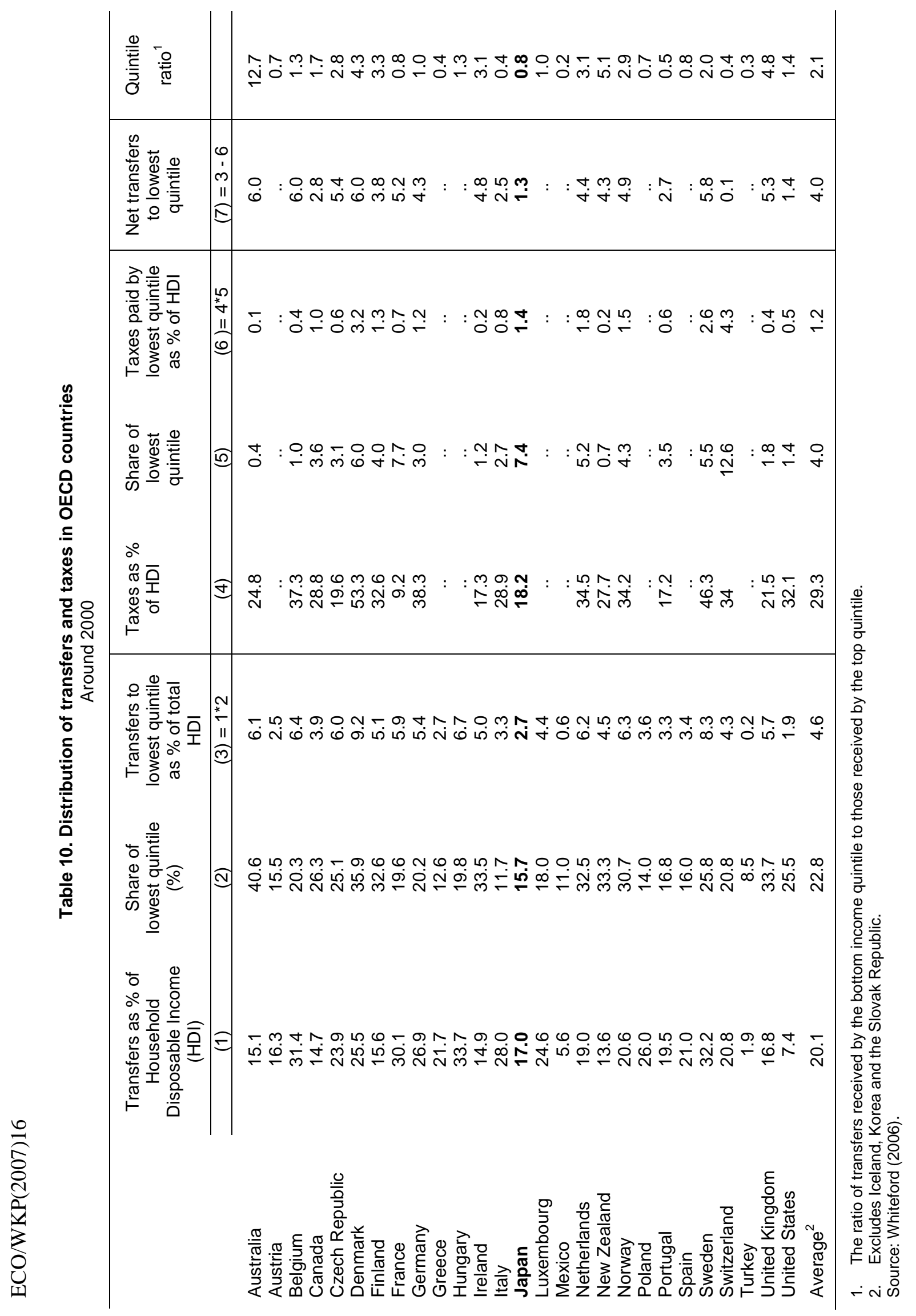


24. The share of the working-age population receiving income-replacing benefits also illustrates the relatively limited coverage of social spending (Table 11). The proportion receiving benefits in Japan was the lowest, at $11.4 \%$, of any of the 16 countries for which data are available, even though the proportion of the working-age population that receives old-age and survivor benefits was above the OECD mean. Indeed, Japan was one of only two countries in which the share of the population receiving benefits from the government was below the relative poverty rate. The biggest difference between the OECD mean and Japan is in the area of unemployment benefits, reflecting the relatively low number of unemployed. Moreover, strict eligibility conditions and the short duration of benefits in Japan also reduce the proportion of unemployed receiving benefits to $34 \%$ compared to an OECD average of $92 \% .^{32}$

25. The number of recipients of social assistance/support for lone parents is exceptionally low at $0.3 \%$ of the working-age population in Japan, compared to an OECD mean of 2.6\%. Moreover, it has fallen from $0.5 \%$ in $1980 \mathrm{~s}$ despite the increase in poverty during the $1990 \mathrm{~s}$. Part of the difference is explained by the fact that the share of the population living in lone-parent households, at $1.3 \%$, is less than half of the OECD average. According to the MHLW, 83\% of single mothers are employed, although about half are non-regular workers. ${ }^{33}$ Even though around $70 \%$ of single mothers receive the childcare allowance for single mothers, $58 \%$ of working single parents in 2000 lived in relative poverty, well above the OECD average of $21 \%,{ }^{34}$ and higher than the $52 \%$ of non-working single parents in relative poverty (Figure 5).

Figure 5. Relative poverty rates in households with children

Households with a head of working age, around the year 2000

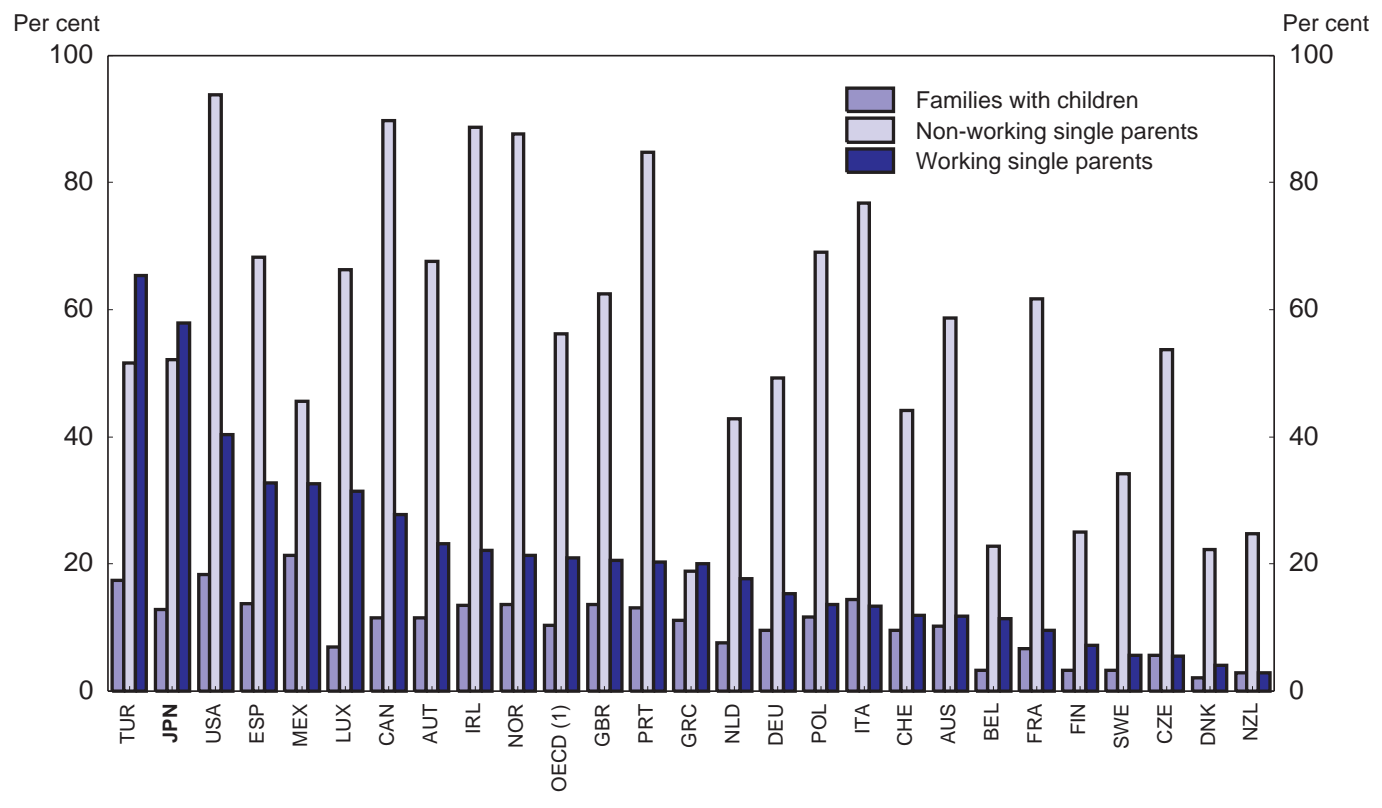

1. Average for 26 countries. Source: OECD, ELS database.

32. The level of benefits, though, is relatively high. The average replacement rate for those who are unemployed for 60 months and qualify for social assistance is around 67\%, compared to an OECD average of $62 \%$ (based on the average for four family types and two earning levels). See Society at a Glance, 2005.

33. In contrast, three-quarters of single fathers who work are regular workers, thus reducing the extent of poverty and illustrating the drawbacks of labour market dualism.

34. Of the single mothers who do not work, $22 \%$ received social assistance in 2003. 
Japan is one of only three OECD countries, along with Greece and Turkey, which have a higher poverty rate for single parents that are working than for those that are not employed. The childcare allowance for single mothers was reformed in 2002 so that the total amount of income rises as earnings from work increases.

26. Widespread poverty among single parents results in a high incidence of poverty among children in Japan. Indeed, the rate of child poverty was $14.3 \%$ in 2000, compared with an OECD average of $12.2 \%$. Given the high cost of schooling and private tutoring institutes, children in poor families are at risk of receiving an inadequate education, thus tending to reduce the growth potential and perpetuating poverty across generations. The most recent PISA tests of student performance show increased stratification of the results for Japan. In contrast to other OECD countries, child poverty is concentrated in working families; $49 \%$ of child poverty is in households with at least two earners and another $49 \%$ in households with one earner. Only $2 \%$ of child poverty is in households with no earners, in contrast to an OECD average of $32 \%$. This suggests relatively little scope to reduce child poverty by boosting employment, which would be highly effective in other OECD countries. Instead, in-work benefits for working parents, together with a reduction in the dualism in employment conditions, appear to be the key.

\section{Taxes and relative poverty}

27. While poor households in Japan receive a low share of transfers, they bear a high tax burden relative to other OECD countries. The lowest income quintile paid $7.4 \%$ of total direct taxes in 2000 compared to an OECD average of $4 \%$ (Table 10). Combining the impact of transfers and taxes, the net transfer to the lowest income quintile in Japan is 1.3\%, compared to an average of 4\% in the OECD area. In sum, the tax and benefit systems increase the income of low-income households by a relatively small amount in Japan. Indeed, Japan is the only OECD country in which the rate of child poverty has been consistently higher after taxes and transfers than before (Figure 6).

Figure 6. Trends in child poverty rates

Per cent in poverty before and after taxes and transfers

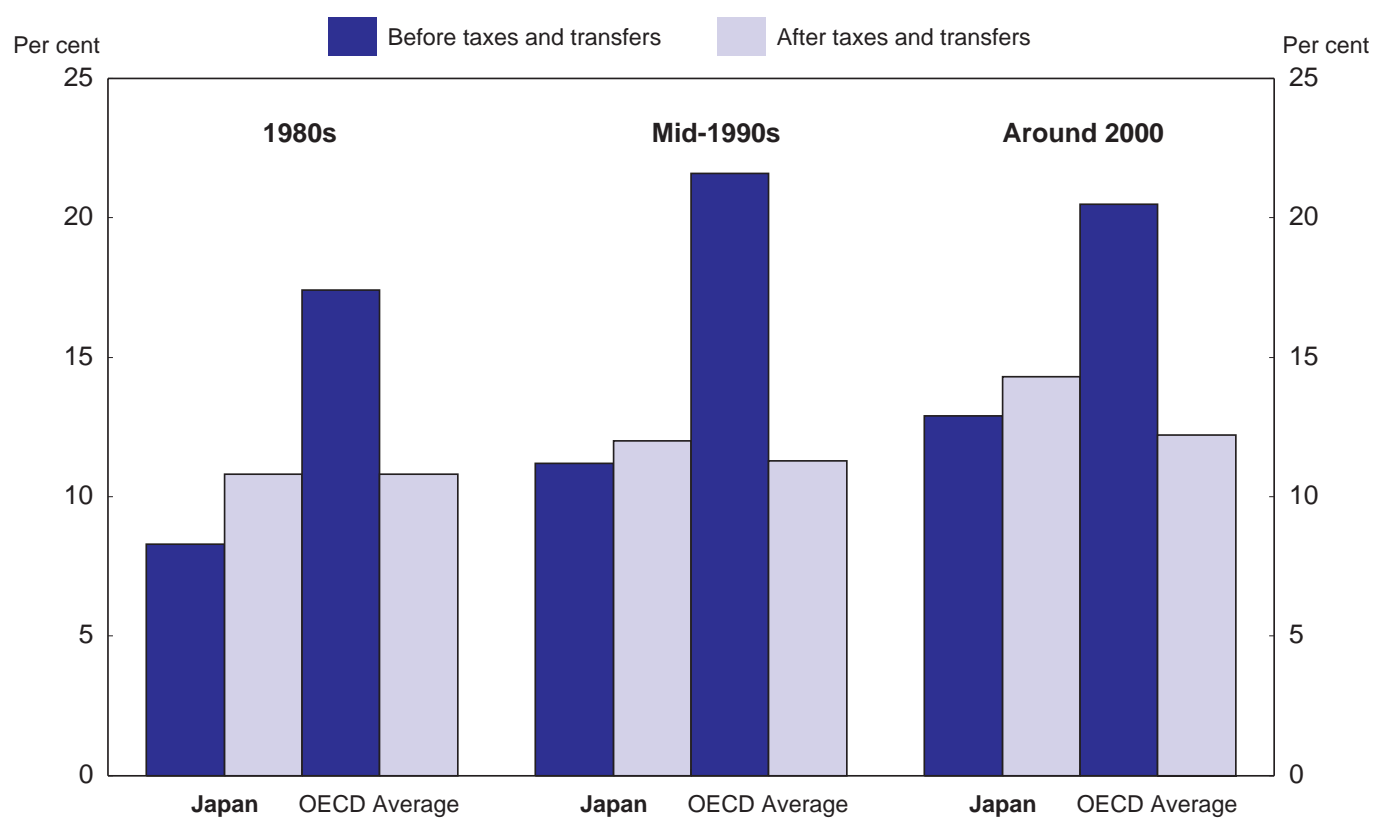

Source: Whiteford and Adema (2006). 


\section{Conclusion}

28. The low level of market income inequality that was characteristic of the post-war era has been converging in recent years to the OECD average. Given the relatively small impact of the tax and benefit systems on income distribution, the level of inequality in disposable income in Japan has risen above the OECD average (Table 12). While population ageing has played a role, there has also been a marked rise in inequality among the 18 to 65 age group as a result of the increasing variance in wages. This trend cannot be explained by differences in the earnings of full-time employees, which have narrowed in recent years. Instead, the greater dispersion of market income is due to the increasing proportion of non-regular workers - primarily part-time employees - who are paid only $40 \%$ as much per hour as full-time employees. The growing dualism in the labour market thus creates serious equity issues, which are exacerbated by the limited mobility between the regular and non-regular segments of the labour market. Dualism also has a negative impact on potential growth, as non-regular workers receive less training by firms, thus limiting their human capital and productivity gains.

29. Rising income inequality in the working-age population has been accompanied by a hike in the rate of relative poverty to one of the highest levels in the OECD area (Table 12). One reason for high poverty is the limited effect of tax and social spending policies, reflecting the below-average level of social spending as a share of GDP, even after taking account of the tax system and mandated private outlays. Moreover, social spending is concentrated in pension and healthcare programmes that primarily benefit the elderly, while outlays for the working-age population are relatively limited. In addition, the proportion of benefits accruing to low-income households is small compared to other OECD countries. On the tax side, the system has become much less progressive in recent years.

30. Recommendations to address inequality and relative poverty are summarised in Box 1 . Given the severe fiscal situation and the rapid pace of population ageing (see Chapter 3 of the 2006 OECD Economic Survey of Japan), there is little scope for additional social spending aimed at the working-age population. Moreover, a broad-based expansion in social programmes may not succeed in substantially reducing poverty rates. Experience in OECD countries shows only a weak relationship between increases in social spending and overall reductions in poverty (Figure 7). Instead, the priority should be to increase the returns from work by reducing labour market dualism and by better targeting existing social programmes on the most vulnerable groups. The priority is single parents, who have a poverty rate of over $50 \%$. This would also help to reduce the rate of child poverty from its currently high level. With $98 \%$ of child poverty in working families, measures to increase employment are unlikely to reduce child poverty significantly. Instead, it is necessary to improve family benefits for employed persons, while limiting the creation of work disincentives and poverty traps. In the absence of such targeted policies, there is likely to be increased pressure to reduce poverty through steps to create a more generous overall welfare state. However, this would require substantial increases in public spending and revenue, with possible adverse economic implications at a time when coping with population ageing and raising potential growth from its low level is a priority in Japan (see Chapter 5 of the 2006 OECD Economic Survey of Japan). In addition to better target social expenditures, the reform of the tax system should aim at reducing the relative share of the tax burden that is borne by low-income households. 


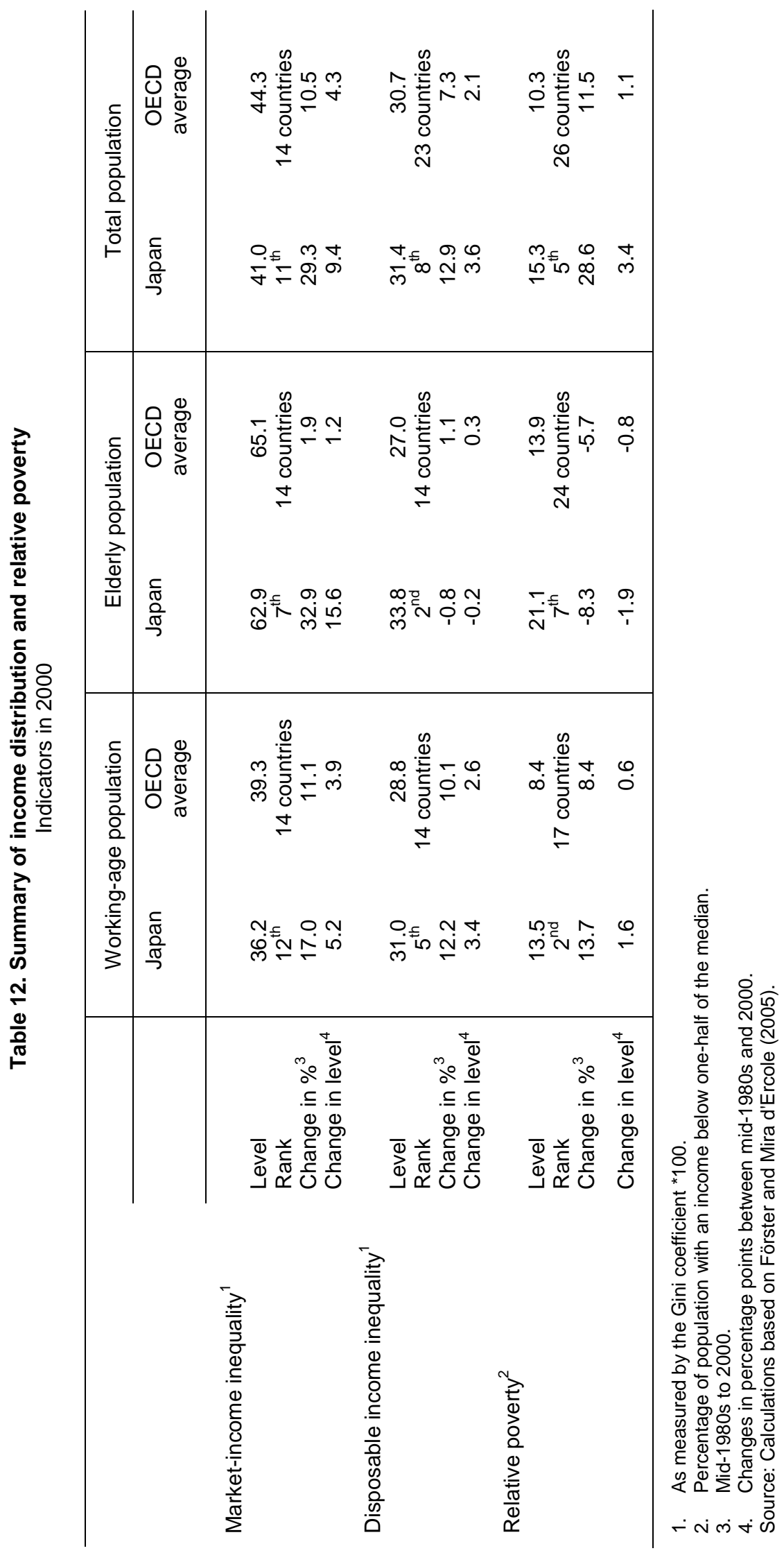




\section{Box 1. Summary of recommendations to address inequality and relative poverty}

Reverse the trend toward increasing labour market dualism through a comprehensive approach

- Reduce employment protection for regular workers to reduce the incentive for hiring non-regular workers to enhance employment flexibility.

- Expand the coverage of non-regular workers by social insurance systems based in workplaces, in part by improving compliance with current insurance systems.

- Increasing training to enhance employability

\section{Policies to contain spending}

- Shift the allocation of social spending to increase the share received by low-income households.

- Target social spending on vulnerable groups, such as single parents, while taking care to limit the creation of poverty traps and work disincentives.

- Take account of income distribution in reforming the tax system.

31. With the budget situation limiting the scope for greater social spending, it is essential to address the underlying factors behind the rise in market income inequality that is boosting inequality in disposable income and relative poverty rates. The key is to reverse the trend toward labour market dualism. According to government surveys, the main factors that encourage the hiring of non-regular workers are their lower labour costs and greater employment flexibility. Reducing dualism, therefore, requires addressing these two factors, while at the same time avoiding measures that would reduce total employment. The first advantage of hiring non-regular workers - lower labour costs - results from lower hourly wages, as well as the exemption of non-regular workers from company-based social insurance systems. While wage rates are set by the private sector, the government should increase the social safety net coverage of non-regular workers to reduce the cost advantage of hiring such workers, possibly accompanied by targeted in-work benefits to prevent unemployment. The second advantage - greater employment flexibility - could be narrowed by either reducing employment protection for regular workers or tightening that of non-regular workers, including through better compliance. However, as the latter approach would likely reduce overall employment, the priority should be to ease the protection of regular workers, thereby reducing the incentive to circumvent strict employment protection by hiring non-regular workers. 
ECO/WKP(2007)16

Figure 7. Changes in social spending and poverty among the working-age population Changes in percentage points, 1995-2000

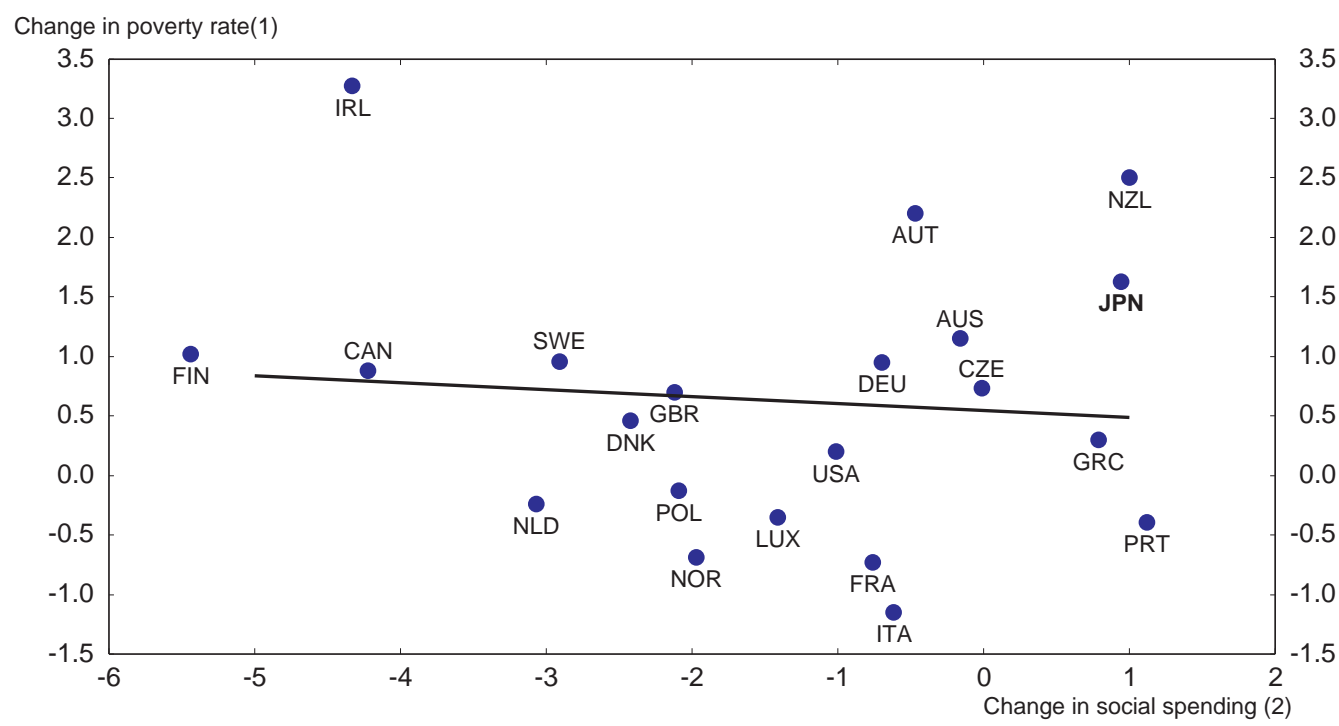

1. Change in the relative poverty rate, defined as a household income that is less than half of the median. A negative value denotes a reduction in poverty rate over the five-year period.

2. Social spending is defined as public and mandatory private social spending on the 18 to 65 age group. Source: OECD, ELS database. 


\section{Bibliography}

Adema, Willem and Maxime Ladaique (2005), "Net Social Expenditure, 2005 Edition”, OECD Social, Employment and Migration Working Papers No. 29, Paris.

Adema, Willem and Peter Whiteford (2005), "Social Spending and Economic Growth in Canada", in Interational Symposium on Social Spending and Economic Growth in OECD Countries, Conference organised by the Korea Institute for Health and Social Affairs, Seoul, November.

Arjona, Roman, Maxime Ladaique and Mark Pearson (2001), "Growth, Inequality and Social Protection", OECD Labour Market and Social Policy Occasional Papers No. 19, Paris.

Bassanini, Andrea, Stefano Scarpetta and Philip Hemmings (2001), "Economic Growth: The Role of Policies and Institutions, Panel Data Evidence from OECD Countries", OECD Economics Department Working Paper No. 283, Paris.

Bauer, John and Andrew Mason (1992), "The Distribution of Income and Wealth in Japan", Review of Income and Wealth, Series 38, Number 4, December.

Burniaux, Jean-Marc, Flavio Padrini and Nicola Brandt (2006), "Labour market performance, income inequality and poverty in OECD countries", OECD Economics Department Working Papers No. 500, Paris.

Cabinet Office (2005a), Annual Report on Japanese Economy and Public Finance, Tokyo.

Cabinet Office (2005b), Annual Report on the National Lifestyle, Tokyo (in Japanese).

Disney, R., Marco Mira d'Ercole and Paul Scherer (1998), “Resources during Retirement”, www.org.

Förster, Michael and Marco Mira d'Ercole (2005), "Income Distribution and Poverty in OECD Countries in the Second Half of the 1990s", OECD Social, Employment and Migration Working Papers No. 22, Paris.

Higuchi, Yoshio and Policy Research Institute, Ministry of Finance (2003), Income Differentials and Social Class in Japan, Tokyo: Nihon Hyouronsya (in Japanese).

Japanese Trade Union Confederation (RENGO) (2006), "Rising Gaps and the Polarization of Society", presentation by Assistant General Secretary Naoto Oumi, 24 February 2006.

Jones, Randall (2005), "Social spending and economic growth in Japan and Korea", in Interational Symposium on Social Spending and Economic Growth in OECD Countries, Conference organised by the Korea Institute for Health and Social Affairs, Seoul, November.

Mira d'Ercole, Marco (2006), "Income Inequality and Poverty in OECD Countries: How Does Japan Compare", Th Japanese Journal of Social Security Policy, (July).

National Institute of Population and Social Security Research (2003), Social Security in Japan, Tokyo. 
OECD (2003), Babies and Bosses: Reconciling Work and Family Life, Vol. 2, Austria, Ireland and Japan, Paris.

OECD (2004), Employment Outlook, Paris.

OECD (2005), Economic Survey of Japan, Paris.

Tachibanaki, Toshiaki (2000), "Japan is not a welfare state, but", in R. Griffits and T. Tachibanaki, eds., From austerity to affluence, London: Macmillan.

Tachibanaki, Toshiaki (2005), Confronting Income Inequality in Japan, Cambridge, Massachusetts: The MIT Press.

Whiteford, Peter (2006), “The Welfare Expenditure Debate: 'Economic Myths of the Left and the Right' Revisited", Economic and Labour Relations Review.

Whiteford, Peter and Willem Adema (2006), "Child Poverty in OECD Countries: Is Work the Answer" mimeo. 


\section{Annex 1}

\section{The measurement of inequality and poverty}

\section{Characteristics of the data ${ }^{35}$}

1. The data used in this paper are drawn from the OECD's income distribution database, which collects inequality and poverty information from national sources based on a standardised methodology regarding data characteristics. Because of the emphasis on changes in income inequality and poverty, an effort was made to improve data comparability over time for individual countries. The use of a common questionnaire and methodology also allows better comparisons of levels of different variables across countries. The basic concept underlying the data is that of household disposable income. To account for possible scale economies in consumption, household income is "equivalised" using the square root of household size. ${ }^{36}$ Separate data are available for persons of working-age (18 to 65) and retirement age (over 65) and for households with different characteristics (age of household head, presence of children and of an adult partner, employment status of household members).

2. Despite efforts to ensure country comparability, some differences in national data escape "standardisation" across countries. Some of the main features that may affect comparisons across countries and time include the following:

- Differences in the definition of households. For most countries, households refer to a group of people having common provisions for essential items, but in some countries they may refer to people living in the same home. More restrictive definitions of "household" will tend to reduce household size and equivalised income (and increase poverty rates).

- Period over which income is assessed. Data generally refer to income in the year preceding the interview. However, even for countries where annual income data are shown, income may be assessed over a shorter reference period and then converted to an "annual equivalent". Countries using shorter reference periods to measure income will generally display higher poverty rates because of the greater volatility of weekly income and higher probability of recording periods of "temporary" income shortfalls. In the case of Japan, income data are reported on an annual basis.

- Gross and net income. For Japan and 21 other OECD countries, all income components are reported on a "gross" basis, i.e. before deduction of direct and payroll taxes (social security contributions) paid by individuals and households. However, there are differences in the way taxes are computed, with some countries (including Japan) relying on data as reported by respondents, and others on information from tax records, and others yet on values "imputed" though micro simulation models applied to individual records.

- Income components. The data generally distinguish between earnings (broken down into the earnings of the household head, the spouse and other household members); self-employment

35. This section draws heavily on Annex 1 of Förster and Mira d'Ercole (2005).

36. This implies that, to keep economic well-being unchanged, household income needs to increase by $41 \%$ when a second member joins the household, by a further $32 \%$ for a third, and by $26 \%$ for the fourth. 
income; capital income (rents, dividends and interest); and current transfers received by households. Capital income is generally limited to income paid in cash. Current transfers refer to cash transfers paid by government to individuals and households. Because of the exclusion of inkind transfers, changes in the nature of government support (e.g. from provision of social housing at subsidised rates to housing benefits paid in cash) may distort results.

- Recording of private pensions. There are large differences across countries in terms of the nature and institutional arrangements governing private pensions. These differences relate both to their mandatory or voluntary character, and to the nature of the agencies that are responsible for their management and administration (i.e. in some cases, they may be part of the social security administration, while in others they may be fully private). Also, private pensions are not always identified separately in the household surveys of some countries. Because of these differences, private pensions that are substantially similar may be recorded differently across countries.

\section{Comparison of data from Japanese government surveys}

3. There are a number of government surveys that provide information on income distribution in Japan (Figure A1.):

- The Comprehensive Survey of Living Conditions of the People on Health and Welfare by the Ministry of Health, Labour and Welfare (MHLW), which carries out a large-scale survey every three years. Its Income Survey includes about 32000 households and replies are received by $80 \%$ of those surveyed. The Survey covers all items in gross income.

- The Survey on the Redistribution of Income by the Ministry of Health, Labour and Welfare. The sample data is taken from the Comprehensive Survey of Living Conditions of the People on Health and Welfare.

- The National Survey of Family Income and Expenditure by the Ministry of Internal Affairs and Communications, which is based on a sample of 60000 households.

- The Family Income and Expenditure Survey by the Ministry of Internal Affairs and Communications, which is based on only 8000 households. 
Figure A1. Different measures of the Gini coefficient in Japan Gini coefficient * 100 for disposable income

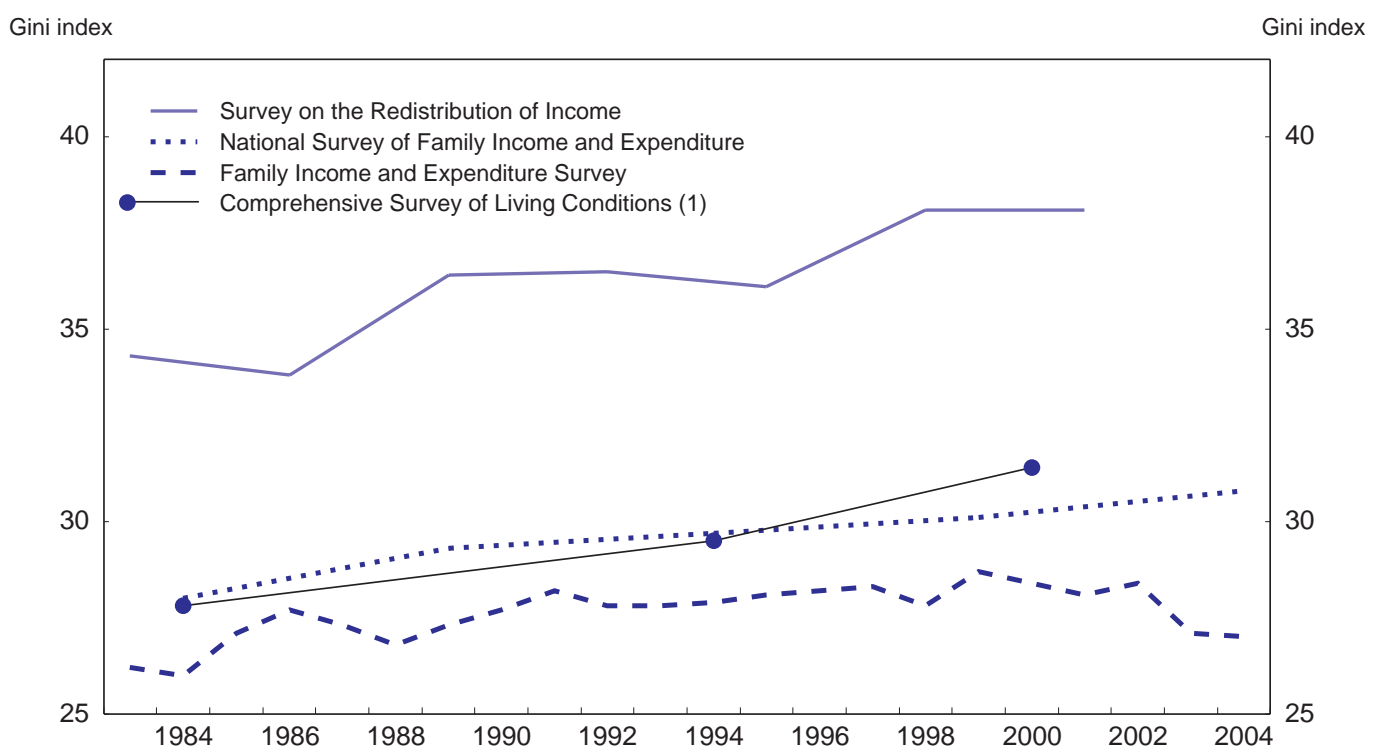

1. Survey data used by the OECD to calculate an internationally consistent estimate of Gini coefficients.

Source: Ministry of Health, Labour and Welfare, Ministry of Internal Affairs and Communications and Förster and Mira d'Ercole (2005).

4. All four Surveys report a rise in income inequality between the mid-1980 and 2000, although by differing amounts. The data from the Comprehensive Survey of Living Conditions of the People on Health and Welfare (on which the comparative OECD study is based), gives a 12.9\% rise in income inequality for the total population, compared to $11.1 \%$ in the Survey on the Redistribution of Income, $8.3 \%$ in the National Survey of Family Income and Expenditure and 6.1\% in the Family Income and Expenditure Survey.

5. The results of the Comprehensive Survey of Living Conditions, which is used by the OECD for its comparative analysis, and the Survey on the Redistribution of Income, are similar as expected as the data comes from the same survey by MHLW (Table A1). The Comprehensive Survey exclude households headed by a person below the age of 17 and all individuals whose age is not recorded, thus allowing comparisons of working-age and elderly populations, as shown in Tables 1 and 3. In contrast, the data from the Survey on the Redistribution of Income that are available to the OECD Secretariat do not have separate measures of inequality for the working-age and elderly populations. However, persons with an income three times larger than the standard deviation are excluded from the Comprehensive Survey $1.6 \%$ of all persons in 1995 and $1.3 \%$ in 2000), thus reducing inequality measures that are sensitive to the high end of the income distribution. In sum, the Gini coefficients from the two Surveys agree that government policies have had a growing impact on reducing inequality but have been more than offset by the rising inequality in market incomes. The main difference between them concerns the level of inequality. The Gini coefficients calculated from the Comprehensive Survey by the OECD are adjusted for family size as noted above, thus making them significantly less than the Gini coefficient from the Survey on the Redistribution of Income, which is not adjusted. 
Table A1. Comparison of different measures of the Gini coefficient The Gini coefficient multiplied by 100 for the total population

\begin{tabular}{|c|c|c|c|c|c|c|}
\hline & \multicolumn{2}{|c|}{ Market income } & \multicolumn{2}{|c|}{ Disposable income } & \multicolumn{2}{|c|}{$\begin{array}{c}\text { Impact of } \\
\text { government policies }^{1}\end{array}$} \\
\hline & $\begin{array}{l}\text { Survey of } \\
\text { living } \\
\text { conditions }^{2}\end{array}$ & $\begin{array}{l}\text { Survey on } \\
\text { income } \\
\text { distribution }\end{array}$ & $\begin{array}{l}\text { Survey of } \\
\text { living } \\
\text { conditions }\end{array}$ & $\begin{array}{l}\text { Survey on } \\
\text { income } \\
\text { distribution }\end{array}$ & $\begin{array}{l}\text { Survey of } \\
\text { living } \\
\text { conditions }^{2}\end{array}$ & $\begin{array}{l}\text { Survey on } \\
\text { income } \\
\text { distribution }\end{array}$ \\
\hline $\begin{array}{l}\text { Mid-1980s }{ }^{4} \\
\text { Mid-1990s } \\
\text { Around } 2000^{6}\end{array}$ & $\begin{array}{l}31.7 \\
36.9 \\
41.0\end{array}$ & $\begin{array}{l}39.8 \\
43.9 \\
47.2\end{array}$ & $\begin{array}{l}27.8 \\
29.5 \\
31.4\end{array}$ & $\begin{array}{l}34.3 \\
36.5 \\
38.1\end{array}$ & $\begin{array}{l}3.9 \\
7.4 \\
9.6\end{array}$ & $\begin{array}{l}5.5 \\
7.4 \\
9.1\end{array}$ \\
\hline $\begin{array}{l}\text { Change, mid-1980s } \\
\text { Percentage points } \\
\text { Per cent }\end{array}$ & $\begin{array}{r}9.3 \\
29.3\end{array}$ & $\begin{array}{r}7.4 \\
18.6\end{array}$ & $\begin{array}{r}3.6 \\
12.9\end{array}$ & $\begin{array}{r}3.8 \\
11.1\end{array}$ & $\begin{array}{r}5.7 \\
146.2\end{array}$ & $\begin{array}{r}3.6 \\
65.5\end{array}$ \\
\hline
\end{tabular}

1. Percentage point difference between the Gini coefficients for market income and disposable income.

2. As reported in the OECD comparative estimates (Förster and Mira d'Ercole, 2005), which for Japan uses the data from the Comprehensive Survey of Living Conditions by the Ministry of Health, Labour and Welfare.

3. The Survey on the Redistribution of Income by the Ministry of Health, Labour and Welfare

4. 1984 for Japanese estimate. 1985 for OECD estimate.

5. 1993 for Japanese estimate. 1994 for OECD estimate.

6. 1999 for Japanese estimate. 2000 for OECD estimate.

Source: The OECD comparative estimates based on the Comprehensive Survey of Living Conditions are reported in Förster and Mira d'Ercole (2005).

6. The Gini coefficients from the Comprehensive Survey of Living Conditions of the People on Health and Welfare and the Survey on the Redistribution of Income are higher than the other two estimates shown in Figure A1. This reflects the fact that the Family Income and Expenditure Survey and the National Survey of Family Income and Expenditure by the Ministry of Internal Affairs and Communications exclude single-person households. The two Surveys by the MHLW thus give a more complete picture of trends in inequality.

\section{The impact of taxes and social spending on income distribution}

7. Using the Survey on the Redistribution of Income, it is possible to distinguish between the impact of taxes and social spending on income distribution. The redistributive effect of the tax system has been relatively small and declining since 1993. In contrast, the impact of social spending is much larger and has been increasing. To some extent, this result, which is for the entire population, reflects the influence of rising pension outlays.

\section{Gross versus net public social spending}

8. The tax system affects social expenditure through several channels (Table A2):

- Direct taxation, including social security contributions paid on cash transfers. In Japan, direct taxes on cash benefits are low, reflecting reduced taxation of pension benefits and the exemption of child, unemployment and social assistance benefits.

- Indirect taxation levied on goods and services bought by benefit recipients. The value-added tax (the consumption tax) in Japan is set at 5\% compared to rates between $13 \%$ and $21 \%$ in most European countries. 
- Tax breaks with a social purpose, such as tax expenditures for families with children and favourable treatment of contributions to private health plans. Such tax breaks amount to $1 \%$ of GDP in Japan.

Table A2. Net public social spending in OECD countries Per cent of GDP in 2001

\begin{tabular}{ccrrr}
\hline & & Japan & United States & OECD average $^{1}$ \\
\cline { 3 - 5 } 1 & Gross public social spending & 16.9 & 14.7 & 20.4 \\
2 & Direct taxes on cash benefits & 0.2 & 0.5 & 1.2 \\
3 & Indirect taxes on cash benefits & 0.6 & 0.3 & 1.8 \\
4 & Net direct public social spending & 16.1 & 13.9 & 17.4 \\
& $4=1-2-3$ & 1.0 & 2.0 & 0.5 \\
5 & Net tax breaks & 17.1 & 15.9 & 17.9 \\
6 & Net public social spending & & & \\
& $6=4+5$ & & & \\
\hline
\end{tabular}

1. Average of 23 countries. Greece, Hungary, Luxembourg, Poland, Portugal, Switzerland and Turkey are not included.

2. Includes social security contributions.

Source: Adema and Ladaique (2005).

9. Direct and indirect taxation has a relatively small impact in Japan, reducing social expenditure by $0.8 \%$ of GDP, compared to an OECD average of 3\% (Table A2). In particular, such taxes reduced social expenditure by between $5 \frac{1}{2}$ and $71 / 2$ per cent of GDP in Denmark, Finland and Sweden. In addition, tax breaks with a social purpose are $1 \%$ of GDP, twice as high as the OECD average. In sum, the tax system substantially narrows the gap in public social spending between Japan and other countries.

\section{Relative versus absolute poverty ${ }^{37}$}

10. The choice of the poverty threshold - the income threshold below which a person is considered poor - crucially affects the calculation of poverty rates. Two categories of thresholds are commonly used:

a) Absolute poverty based on the cost of a basket of basic "necessities". The threshold of poverty is constant over time in real terms.

b) Relative poverty based on a percentage of an indicator of the average "standard of living", typically the median (or the mean) of the entire distribution. The threshold of poverty is allowed to change over time.

Both approaches have benefits and drawbacks. An advantage of absolute poverty is that it more closely reflects the evolution of the standard of living of poor persons. ${ }^{38}$ From a policy perspective, absolute thresholds provide a fixed target for social assistance programmes, which facilitates the assessment of antipoverty policies.

11. However, the calculation of absolute poverty thresholds confronts difficult conceptual and statistical issues, especially when international comparisons are involved. First, it is unclear that basic necessities are identical across countries. Second, international comparisons of absolute thresholds require "appropriate" exchange rates, typically some type of purchasing-power-parity (PPP) exchange rate. While

37. This section draws on Burniaux et al. (2006).

38. For example, a broad-based drop of income across deciles would raise poverty rates calculated with absolute thresholds but would leave unchanged those calculated using relative thresholds. 
PPP exchange rates have been calculated to compare GDP or national consumption levels in different countries, they are not appropriate for comparing poverty cut-offs. ${ }^{39}$ Third, the choice of a price index to update absolute thresholds within each country also raises further difficulties. ${ }^{40}$

12. Because of the conceptual and statistical issues involved in the calculation of absolute poverty measures, most international studies rely on relative poverty measures. This paper as well focuses on the level of relative poverty, using 50\% of median income as the threshold. It should be noted that an increase in relative poverty may result from a rise in average income, which does not imply a deterioration of the living standard of the poor.

39. For example, food is less expensive in the United States than in other OECD countries. As the share of food in the expenditures of poor persons is higher than that of the average household, the use of the PPP exchange rate to convert the absolute thresholds of different countries into a common unit would overstate US absolute poverty compared to other OECD countries.

40. Absolute poverty thresholds are usually updated using the overall consumer price index (CPI). However, the growth rate of the overall CPI index is an imperfect indicator of the increase of living costs for lowincome families as their expenditure pattern is different from that of average households. 


\section{Annex 2}

\section{The development of social spending in Japan}

1. The development of the social welfare system in Japan is based on Article 25 of the 1947 Constitution:

a) All people shall have the right to maintain minimum standards of wholesome and cultured living.

b) The State must make efforts to promote and expand social welfare, social security and public health services to cover every aspect of the life of the people.

The major steps were the introduction of public pension and health insurance systems in 1961 and long-term nursing care insurance in 2000. In 1972, family and child allowances were introduced, followed by the introduction of price indexation for pensions, as well as increases in the coverage and payments for pension programmes and health insurance in 1973. The following year, unemployment insurance, introduced on a limited scale in 1947, was expanded into the Employment Insurance System.

2. However, the initial momentum towards the development of an extensive social safety net was subsequently slowed by a variety of factors. First, 1973 marked the end of the high-growth era, encouraging a more modest vision of government's capacity to provide social welfare. Second, government budget deficits ballooned in the 1970s and again in the 1990s, prompting spending restraint. Third, as the speed of population ageing became apparent, the plans for the development of the safety net became less ambitious. Fourth, the traditional roles played by families and firms and the high household saving rate limited the perceived need for public welfare programmes (Tachibanaki, 2000).

3. Public social spending remained fairly constant at around 11\% of GDP from 1980 until 1991 in the context of low unemployment and a relatively young population (Figure 3). However, it increased significantly to almost $17 \%$ during the 1990s, while the average level in the OECD area was about the same in both 1990 and 2000. About two-thirds of the rise in social spending as a share of GDP in Japan was due to outlays for pension and survivor benefits (Panel B). Health spending, an area also driven in part by population ageing, accounted for most of the remaining increase. 


\section{WORKING PAPERS}

The full series of Economics Department Working Papers can be consulted at www.oecd.org/eco/Working_Papers/

555. Improving the efficiency of health care spending: selected evidence on hospital performance (May 2007) Espen Erlandsen

554. Cross-country analysis of efficiency in OECD health care sectors: options for research (May 2007) Unto Häkkinen and Isabelle Joumard

553. What promotes fiscal consolidation: OECD country experience (May 2007) Stéphanie Guichard, Mike Kennedy, Echkard Wurzel and Christophe André

552. Globalisation and the macroeconomic policy environment (April 2007) Karine Hervé, Isabell Koske, Nigel Pain, Franck Sédillot

551. Why has core inflation remained so muted in the face of the oil shock? (April 2007) Paul van den Noord and Christophe André

550. Housing markets and adjustments in monetary union (April 2007) Peter Hoeller and David Rae

549. Financial markets in Iceland (March 2007) Peter Tulip

548. The political economy of delaying fiscal consolidation (March 2007) Boris Cournède

547. The impact on growth of higher efficiency of public spending on schools (March 2007) Frédéric Gonand

546. Performance indicators for public spending efficiency in primary and secondary education (February 2007) Douglas Sutherland, Robert Price, Isabelle Joumard and Chantal Nicq.

545. Monetary policy and macroeconomic stability in Latin America: the cases of Brazil, Chile, Colombia and Mexico

(February 2007) Luiz de Mello and Diego Moccero

544. The Brazilian "tax war": the case of value-added tax competition among the states (February 2007) Luiz de Mello

543. Public spending efficiency: institutional indicators in primary and secondary education (January 2007) Frédéric Gonand, Isabelle Joumard and Robert Price

542. Enhancing turkey's growth prospects by improving formal sector business conditions (January 2007) Rauf Gönenç, Willi Leibfritz, Gökhan Yilmaz

541. Fiscal relations across levels of government in Australia (January 2007) Vassiliki Koutsogeorgopoulou

540. Russian manufacturing and the threat of 'Dutch Disease': A comparision of competitiveness developments in Russia and Ukrainian industry

(January 2007) Rudiger Ahrend, Donato de Rosa and William Tompson

539. Stimulating innovation in Russia: The role of institutions and policies 


\section{ECO/WKP(2007)16}

(January 2007) Christian Gianella and William Tompson

538. Healthcare reform in Russia: problems and prospects (January 2007) William Tompson

537. A golden rule for Russia? How a rule-based fiscal policy can allow a smooth adjustment to the new terms of trade

(January 2007) Christian Gianella

536. From "clientelism" to a "client-centred orientation"? The challenge of public administration reform in Russia (January 2007) William Tompson

535. Has the rise in debt made households more vulnerable?

(December 2006) Nathalie Girouard, Mike Kennedy and Christophe André

534. Social security reform in Brazil: Achievements and remaining challenges

(December 2006) Fabio Giambiagi and Luiz de Mello

533. Improving labour utilisation in Brazil

(December 2006) Luiz de Mello, Naércio Menezes Filho and Luiz G. Scorzafave

532. Boosting innovation performance in Brazil

(December 2006) Carlos H. de Brito Cruz and Luiz de Mello

531. Consolidating macroeconomic adjustment in Brazil

(December 2006) Luiz de Mello and Diego Moccero

530. Product market regulation in the non-manufacturing sectors of OECD countries: Measurement and highlights (December 2006) Paul Conway and Giuseppe Nicoletti

529. The Turkish pension system: further reforms to help solve the informality problem

(November 2006) Anne-Marie Brook and Edward Whitehouse

528. Policies to improve Turkey's resilience to financial market shocks

(November 2006) Anne-Marie Brook.

527. Upgrading Japan's innovation system to sustain economic growth (November 2006 Randall S. Jones and Tadashi Yokoyama

526. Strengthening the integration of Japan in the world economy to benefit more fully from globalisation (November 2006) Randall S. Jones and Taesik Yoon

525. OECD's FDI regulatory restrictiveness index: Revision and extension to more economies (November 2006) Sven Blöndal and Alain de Serres

524. Globalisation and inflation in the OECD economies

(November 2006) Nigel Pain, Isabell Koske and Marte Sollie

523. Identifying determinants of Germany's international price competitiveness - A structural VAR approach (November 2006) Martin Meurers

522. Short-term pain for long-term gain: the impact of structural reform on fiscal outcomes in EMU (November 2006) Paul van den Noord and Boris Cournède

521. Interactions between monetary and fiscal policy: How monetary conditions affect fiscal consolidation (November 2006) Rudiger Ahrend, Pietro Catte and Robert Price 
520. Restoring fiscal sustainability in the Euro Area: raise taxes or curb spending? (October 2006) Boris Cournède and Frédéric Gonand

519. Should Measures of Fiscal Stance be Adjusted for Terms of Trade Effects (October 2006) David Turner

518. Monetary policy and inflation expectations in Latin America: Long-run effects and volatility spillovers (October 2006) Luiz de Mello and Diego Moccero

517. Social safety nets and structural adjustment (September 2006) Paul van den Noord, Nathalie Girouard and Christophe André

516. Adapting the Icelandic education system to a changing environment (September 2006) Hannes Suppanz

515. Forecasting monthly GDP for Canada (September 2006) Annabelle Mourougane

514. Finland's housing market: reducing risks and improving policies (September 2006) Laura Vartia

513. The Danish housing market: Less subsidy and more flexibility (September 2006) Espen Erlandsen, Jens Lundsgaard and Felix Huefner

512. Labour market reform in Germany: How to improve effectiveness (September 2006) Eckhard Wurzel

511. Removing obstacles to employment for women in Ireland (September 2006) Boris Cournède

510. Assessing Russia's non-fuel trade elasticities: Does the Russian economy react "normally" to exchange rate movements?

(September 2006) Christian Gianella and Corinne Chanteloup

509. Regulation, competition and productivity convergence

(September 2006) Paul Conway, Donato De Rosa, Giuseppe Nicoletti and Faye Steiner

508. Improving education achievement and attainment in Luxembourg to compete in the labour market (September 2006) David Carey and Ekkehard Ernst

507. Raising economic performance by fostering product market competition in Germany (August 2006) Andrés Fuentes, Eckhard Wurzel and Andreas Reindl

506. Regulation of financial systems and economic growth (August 2006) Alain de Serres, Shuji Kobayakawa, Torsten Sløk and Laura Vartia 